BANCA D'ITALIA

E U R O S I S T E M A

Questioni di Economia e Finanza

(Occasional Papers)

The tax system and the financial crisis

by Vieri Ceriani, Stefano Manestra, Giacomo Ricotti, Alessandra Sanelli and Ernesto Zangari 

13 BANCA D'ITALIA

E U ROS I S T E MA

\section{Questioni di Economia e Finanza}

(Occasional papers)

The tax system and the financial crisis

by Vieri Ceriani, Stefano Manestra, Giacomo Ricotti, Alessandra Sanelli and Ernesto Zangari

Number 85 - January 2011 
The series Occasional Papers presents studies and documents on issues pertaining to the institutional tasks of the Bank of Italy and the Eurosystem. The Occasional Papers appear alongside the Working Papers series which are specifically aimed at providing original contributions to economic research.

The Occasional Papers include studies conducted within the Bank of Italy, sometimes in cooperation with the Eurosystem or other institutions. The views expressed in the studies are those of the authors and do not involve the responsibility of the institutions to which they belong.

The series is available online at www.bancaditalia.it. 


\title{
THE TAX SYSTEM AND THE FINANCIAL CRISIS
}

\author{
by Vieri Ceriani, Stefano Manestra, Giacomo Ricotti, Alessandra Sanelli \\ and Ernesto Zangari*
}

\begin{abstract}
This paper investigates the effects of the tax system on the economic factors that triggered the financial crisis. We examine three cases in which the tax regime interacted with these factors, reinforcing them. First, we focus on the taxation of residential building: while the importance of capital gains taxes is disputed, the deductibility of mortgage interest may have contributed to the financial crisis by creating some of the raw materials for the securitization industry. Second, a narrow perspective on the tax treatment, together with specific provisions, may have fostered performance-based remuneration of managers, resulting in overemphasis of short-term profitability and incentive to excessive risk-taking. Third, the securitization process, which played a key role in the outbreak of the financial crisis, was accompanied by opportunities for tax arbitrage and reduction of the overall tax wedge paid by investors, through offset of incomes that are ordinarily taxed at different rates; a de facto exemption of CDS premiums received by non-residents supplemented the tax arbitrage.
\end{abstract}

JEL Classification: H2, G1.

Keywords: taxation, financial crisis, housing market, stock options, securitization, credit default swaps.

\section{Contents}

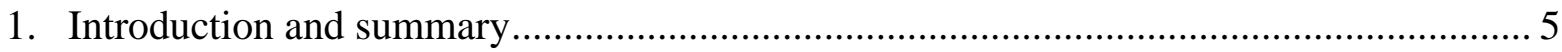

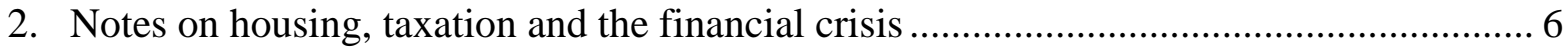

2.1. The housing sector, the economic system and monetary policy .............................. 7

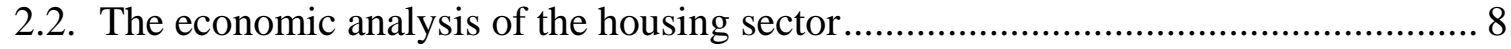

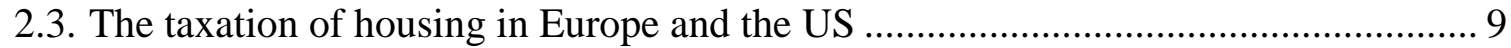

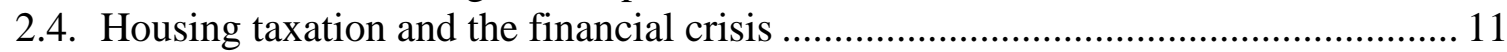

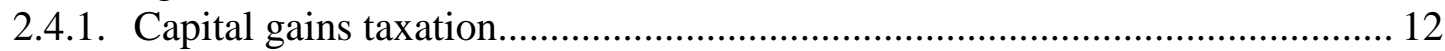

2.4.2. Mortgage interests deductibility .......................................................... 13

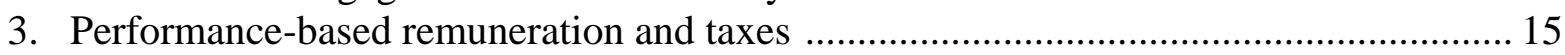

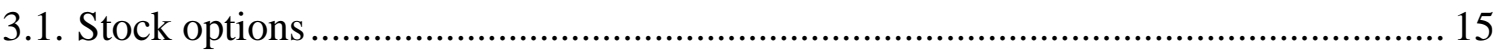

3.2. Venture capital, private equity, hedge funds: the "carried interest" controversy ..... 24

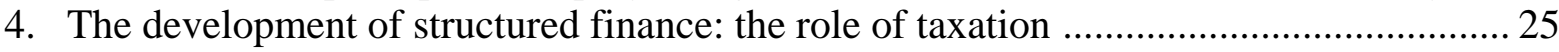

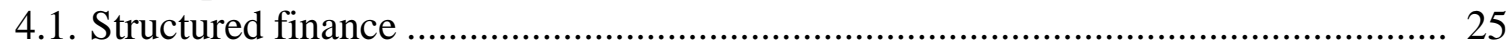

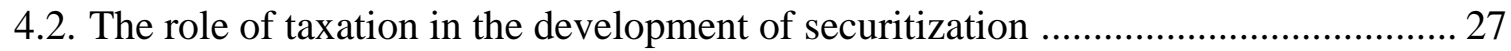

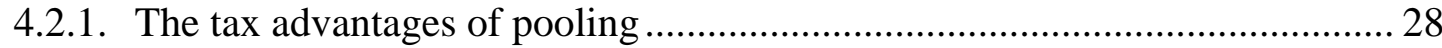

4.2.2. The US tax treatment of special purpose vehicles ..................................... 28

4.2.3. The taxation of credit default swaps .............................................................. 29

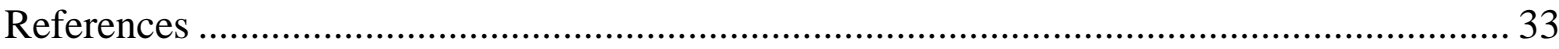

Bank of Italy, Tax Department. The views expressed in this paper are those of the authors and do not commit the Bank of Italy. Although this paper is the product of a joint effort, V. Ceriani wrote Section 1, E. Zangari Section 2, A. Sanelli Section 3, G. Ricotti Sections 4.1, 4.2.1 and 4.2.2, and S. Manestra Section 4.2.3. 



\section{Introduction and summary}

This paper develops the thoughts initially presented at a conference on "Tax policy and the financial crisis" held in April 2009 at Bocconi University in Milan, where we tentatively grappled with the possible effects of the tax system on the economic factors that triggered the financial crisis. Did any features of the tax system influence the build-up of the crisis, and, if so, how?

This paper does not give a comprehensive answer, but highlights some of the observations, doubts and evidence that have been put forward so far. Our starting point is that taxation is an important factor, but usually not the most important driver of economic trends. We have sought to identify cases in which the fiscal regime interacted with other factors and reinforced them. First of all, we have not dealt with the tax biases that favour debt finance and are inherent in corporation tax systems. This issue, highlighted by the IMF (2009) and others, has triggered some proposals for reforming the corporation tax through the introduction of an allowance for corporate equity (ACE): i.e., a deduction for a notional return on own capital. We have concentrated on three more specific fields: the taxation of residential building and the deductibility of mortgage interest (section 1), the taxation of stock options and other performance-based remuneration (section 2) and the interaction between securitization and the tax system (section 3 ).

In most narratives of the financial crisis, the dynamics of the US housing market and the financial structure that was built on it play a decisive role. Not surprisingly, many commentators have found fault with some tax rules that may have contributed to overheating the housing market. In particular, attention has focused on the tax treatment of residential housing capital gains and on the deductibility of interest expense on mortgages.

Some observers argue that the repeal of residential housing capital gains taxation in 1997 may have fuelled the housing bubble. However, both the OECD and the IMF do not believe this factor played a significant role, and academic research on the dynamics of the US housing market tends to concur.

The role of the mortgage interest deductibility in the crisis is also controversial. The relevant US tax rules were not changed significantly in the last decade. The housing boom was geographically uneven, although the federal tax system is nationwide. And housing prices went up both in countries where interest was deductible and in countries where it was deductible only within limits or not at all. Nevertheless, some commentators think this tax break acted like a catalyst in a chemical reaction: it did not cause the bubble, but it may well have accelerated the run-up in prices. It remains true that the US regime is among the most generous by international standards. While all other countries allow interest deductibility only for the purchase or renovation of residential buildings, the US tax code extends this allowance to other purposes ("home equity loan"); moreover, the relatively generous limits to the benefit are capped on the amount of the mortgage, not the amount of interest payments (as is the case in most other countries). Since it is proportional to debt, the tax break is larger for riskier mortgages with higher interest rates and may have contributed to the housing boom, especially in the context of "exuberant" price expectations.

The dramatic rise in stock option remuneration plans and bonuses in the financial sector has also been singled out as playing an important role in triggering the crisis. Although stock-based remuneration seems thoroughly consistent with the objective of setting up a contractual framework aligning the interests of the managers with those of shareholders, it has been criticized because it tends to overemphasize short-term profitability compared with longer-term goals. As the Financial Stability Forum (now Financial Stability Board) has pointed out, this feature is particularly unwelcome in the financial sector, where higher returns may quite easily (more easily than in other sectors) be pursued in a trade-off against higher risks. Did the tax treatment favour stock option schemes over ordinary remuneration? The evidence, taking into account both employee and employer taxes, does not confirm a general tax preference for stock option plans over cash remuneration in many countries, and specifically in the US. Nevertheless, in the US there is 
evidence of a preferential tax treatment on the employer's side, which, in conjunction with other factors, may have contributed to the success of stock-based remuneration plans. In other cases, it is possible that a tax-preference emerged as a consequence of a unilateral perspective, with the favourable tax treatment at employee level prevailing over corporate tax considerations.

In analysing the preconditions of the crisis, it has also been observed that many venture capital and private equity funds engaged in aggressive, highly leveraged corporate restructurings aimed at maximizing short-term performance, often with little regard to the long-term prospects of the firms. The extraordinary growth of private equity transactions prompted greater and greater risktaking and more and more highly leveraged deals. A large part of the blame has been put on the remuneration schemes of the managers, based on "carried interest" (i.e. the part of the realized profits of the fund exceeding a certain threshold), which acted as an incentive to risk-taking. In several countries, especially where private equity funds are most widespread (the UK and the US), the carried interest enjoys favourable tax treatment, consisting in the taxation at preferential capital gains rates rather than at ordinary income tax rates; this encourages aggressive risk-taking by private equity managers.

Preferential personal taxation for managers' remuneration schemes in the financial sector may in fact have been a subsidiary but nonetheless important factor triggering high (excessive) risk exposure. But the assumption of higher risk at company level would have found limits.

The securitization process, allowing the risks assumed by a company to be passed on and diluted in the market, played a fundamental role in shifting risk from financial firms to the whole system and thus in making the crisis systemic. Taxation also appears to have been a factor in securitization. Although the intermediaries involved did not seek preferential tax treatment or pursue tax-avoidance schemes, securitization created opportunities for tax arbitrage and reduction of the overall tax wedge paid by the originator, the special purpose vehicle (SPV) and the final investor. The SPV must be a tax-free vehicle (either a conduit recognized as exempt under domestic tax law or a foreign entity located in a jurisdiction with no direct taxation). In this case, by combining different incomes (interest, capital gains and losses), the SPV makes it possible to pool and offset incomes that are ordinarily taxed at different rates (hence, permitting preferential deductibility of capital losses); furthermore, it allows the taxation of the revenues generated by the underlying original assets to be deferred until the SPV distributes incomes on the securities it has issued (or the securities issued by the SPV are sold and capital gains are realized).

The diffusion of credit default swaps has greatly assisted the securitization process, creating a sort of insurance on the credit risk of the underlying assets. Their tax treatment has also spurred the growth of securitization and created further possibilities of tax arbitrage.

In conclusion, taxation has not been the paramount factor in the securitization process, but it certainly has not created disincentives; indeed, it has created opportunities for tax arbitrage and extra-profits for financial intermediaries able to internalize these opportunities.

\section{Notes on housing, taxation and the financial crisis}

The current financial crisis was triggered by the collapse of the speculative overshoot of house prices, so it is not surprising that many observers have found fault with some housing tax provisions.

The plan of this section is as follows. First, we review the main reasons why the housing market is a very important component of the economic system. Second, we sketch a simple and general economic model of the housing market, which provides a basis for discussion of the effects of some basic housing tax provisions. Third, we compare the tax systems of different countries with 
respect to the US system. Finally, we discuss the possible role of housing tax provisions in the financial crisis.

\subsection{The housing sector, the economic system and monetary policy}

The recent train of events in the housing sector has reignited the debate over its role in business cycle dynamics. For many reasons the housing market is of fundamental importance for the economy.

Economic activity somehow related to housing accounts for an important share of GDP. In Europe this share is estimated at between 5 and 10 per cent (Hilbers et al., 2008, p. 4), while in the US residential investment alone accounts on average for 5 per cent of GDP. ${ }^{1}$ In spite of many differences across countries and over time, the housing market and the business cycle seem to be closely related: real house prices are positively correlated (with some lags) with the economic cycle; residential investment tends to lead the economic cycle. These correlations imply the existence of underlying relationships between overall economic activity and the housing sector. ${ }^{2}$

The housing sector's dynamics play a role in the business cycles especially through the effects on consumption spending, due to the importance of house values in households' balance sheets on both the assets and the liabilities side. ${ }^{3}$

Analysis of the effects of housing on consumption is complicated by the dual role of houses as both an investment and a consumption good; this implies that price changes redistribute wealth across households, so the consumption response will depend on the relative propensity to consume out of wealth of the price-change "winners" and "losers". Another channel through which housing market dynamics impact on consumption, for many scholars the most important one, ${ }^{4}$ is the consequent change in home equity, i.e. the difference between the value of the house and the outstanding debt on the property: home equity can be used as collateral to ease liquidity constraints and, under some conditions, to support spending. In fact, the impact of home equity withdrawal on consumption (and volatility) is ambiguous: home equity permits greater consumption smoothing in the face of adverse shocks and reduces volatility; on the other hand, the endogenous variation of the value of collateralized assets may magnify fluctuations to structural shocks, a "financial

\footnotetext{
Source: US Bureau of Economic Analysis.

On the importance of housing markets for the overall economy and for monetary policy see also ECB (2003). In a recent paper with the self-explanatory title "Housing IS the business cycle", Leamer (2007) argues that the housing sector is very important for the US business cycle and that its dynamics should play a prominent role in the conduct of monetary policy.

3 The home ownership rate - the ratio of owner-occupied units to the total number of occupied units - has increased on average in the last decades in Europe and the US. In Europe it ranges from highs of 83 per cent in Greece, 82 per cent in Spain and 80 per cent in Italy to lows of 42 per cent in Germany, 51 per cent in Denmark and 54 per cent in the Netherlands; the average rate across Europe (excluding the Central and Eastern European countries) is approximately 60 per cent, compared with 68 per cent in the United States (Hilbers et al., 2008, Table 5, p. 20).Housing wealth, defined as the ratio of the value of housing to total financial and non-financial wealth, ranges from 55 to 60 per cent in Europe (Hilbers et al., 2008, Figure 7, p. 21); in the US the figure is approximately 40 per cent (Bucks et al., 2009, p. 28). The ratio of residential debt to GDP is about 66 per cent in Europe overall. Roughly between 1990 and 2006 the ratio increased in many countries, in some cases considerably: it rose from 45 to 78 per cent in the United States, from 55 to 86 per cent in the United Kingdom, and from 5 to 20 per cent in Italy (IMF, 2008, Figure 3.1, p. 3).

4 Buiter (2008) makes the point that changes in house prices due to changes in "fundamentals" (interest rates, building costs, demographics, etc.) entail only redistributive effects in a large class of economic models; in other words, in general there are no wealth effects on consumption associated with such price changes. When changes in house prices reflect a "bubble" component - that is, one not related to "fundamentals" - then wealth effects do exist. The author argues that the basic wealth effect in a benchmark model must only be the one associated with home equity withdrawal, thus an indirect wealth effect. Assuming the existence of other wealth effects may lead to an overstatement of the housing sector's role in business cycles and in the monetary policy transmission mechanism.
} 
accelerator" of the kind proposed, among others, by Bernanke and Gertler (1995) and Kiyotaki and Moore (1997). ${ }^{5}$

In principle, the housing sector plays an important role in the monetary policy transmission mechanism. Changes in interest rates affect private spending directly, through their effects on the cost and availability of credit, and indirectly, through their effects on house prices. The changes in house prices influence consumption through the wealth effects discussed above, and they influence residential investment by making it profitable to increase the stock of housing, given construction costs (Tobin's “q” investment theory applied to the housing sector).

Financial deepening may have changed the housing sector's role in the monetary policy transmission mechanism in fundamental ways. Some argue that financial innovation, by increasing the availability of credit, has reduced its importance in monetary policy transmission, but financial deregulation may have made households more responsive to interest rate changes (see IMF, 2008, pp. 7-8, 16-17 and the references therein).

Many central bankers have recently asserted that monetary policy sometimes should respond to large changes in asset prices, and so also in house prices, when these changes threaten macroeconomic stability. There is, then, a more or less implicit consensus on the importance of the housing sector and on the need to "lean against the wind" when imbalances emerge in the housing market (IMF, 2008, pp. 20-26). When mortgage markets are more developed, the optimal monetary policy may be one that responds not only to overall inflation and the output gap, as in the standard Taylor rule, but also to house price inflation (IMF, 2008, pp. 125-127; see also Leamer, 2007).

\subsection{The economic analysis of the housing sector}

The standard economic analysis of the housing sector posits that the market actually consists of two interrelated markets: one for the existing stock of houses, which determines their price, and one for the new flow of construction, which determines residential investment. ${ }^{6}$

The equilibrium on the market of existing houses requires that owners, as investors, earn the same return on their housing investment as on alternative investments:

$$
R_{H}=\left[\left(1-\tau^{P I T}\right) i^{M}+\delta+\beta+m+\tau^{P}-\left(1-\tau^{C G}\right) E\left(\pi^{H}\right)\right] P_{H}
$$

where $R_{H}$ denotes the marginal value of rental services per period, $\tau^{P I T}$ the relevant personal income tax rate $^{7}, i^{M}$ the financing cost (assumed for simplicity equal to the investor's opportunity cost of funds ${ }^{8}$ ), $\delta$ the depreciation of the stock of existing houses, $\beta$ the risk premium required by the investor to be owner rather than tenant, $m$ the maintenance cost per unit value, $\tau^{P}$ the property tax rate, $\tau^{C G}$ the housing capital gains tax rate, $E\left(\pi^{H}\right)$ the expected housing price appreciation and $P_{H}$ the price of existing houses. The above equation can be also interpreted as follows: in the long run the cost of owning a house should be equal in equilibrium to the cost of renting it, with $R_{H}$ representing the annual cost of renting and the quantity in square brackets representing the user cost of housing or ownership (or "imputed rent"). ${ }^{9}$

Assuming that the rental value $R_{H}$ is decreasing in the stock of houses $\mathrm{H}$ (i.e. $d R_{H} / d H<0$ ), and that the user cost of housing is positive, equation (1) can be interpreted as a (downward sloping) demand function whose slope is steeper the lower is the user cost (Van den Noord, 2005).

\footnotetext{
See IMF (2008), p. 111.

Standard references are Kearl (1979), Topel and Rosen (1988) and Poterba (1984, 1991, 1992).

In the model we assume the case of mortgage interest deductibility, as in the US.

See Poterba (1984), footnote 6.

Hilbers et al (2008), p. 8.
} 
A housing supply function can be easily derived assuming a positive relationship between (net) residential investment and the ratio of house prices over building costs $\left(C_{H}\right)$ (Poterba, 1991). Formally:

$$
H_{t}-H_{t-1}=\Delta H_{t}=\phi\left(P_{H, t} / C_{H, t}\right)-\delta H_{t-1}
$$

The short-run price elasticity of the housing supply is equal to $\phi$; the long-run elasticity is larger and equal to $\phi / \delta$. In this simple model house prices play the same role as the value of the firm's stock in Tobin's q dynamic model for investment.

This simple and quite general demand-supply model of the market of owner-occupied houses predicts that ${ }^{10}$ :

- since the housing supply is basically fixed in the short run, the housing market is subject to price overshooting in the face of demand shocks; the housing market is therefore intrinsically volatile;

- the deductibility of mortgage interest, by reducing the user cost of ownership, decreases the price elasticity of demand; it therefore increases the volatility of the housing market; ${ }^{11}$

- the increase in volatility could have negative effects especially if agents form expectations (also partially) in an extrapolative manner, inducing prolonged price upswings or downswings not linked to "fundamentals"; 12 in the best-case scenario, the choices of households and firms could be temporarily distorted; in the worst-case scenario, a price bubble may form;

- a change in the expected housing price appreciation and more generous tax breaks on housing (for example, lower capital gains tax rates) may generate, in principle and under some conditions, unsustainable dynamics in the housing market. ${ }^{13}$

\subsection{The taxation of housing in Europe and the US}

There is a great diversity of housing tax regimes across countries. ${ }^{14}$ International comparisons are difficult because of the complexity of tax codes (in terms of deductions, exceptions, threshold limits, and so on). Table 1 summarizes the information concerning the tax treatment of mortgage interest expense, imputed income of owner-occupied housing and capital gains on first-home selling for a set of countries comprising the US, UK, Italy, Spain, Ireland, Netherlands, Belgium and Germany. ${ }^{15}$

10 See Van den Noord (2005) and Poterba (1991).

11 In general, the price sensitivity of demand for housing is inversely related to the extent of preferential tax treatment for housing and to the expected rate of house price appreciation (see Van den Noord, 2005).

12 For the US see Case and Shiller (1988). See also the general discussion in Poterba (1991).

13 The model in the text can easily account for disequilibria dynamics. Suppose, for example, that for whatever reason the user cost of ownership becomes equal to zero. This can happen because of a decrease in the (net) mortgage interest rate (for instance, due to more generous interests deductibility and/or lower monetary policy interest rates), given expectations, or a sudden increase in expectations of housing price appreciation, or a decrease in the taxation of housing capital gains, or a combination of these factors. The right-hand side of equation [1] in the text becomes equal to zero; the left-hand side can be equal to zero only when the demand for housing is infinite; with very strong demand for housing there will be pressure on prices in the short run (given the low short-run price elasticity of supply); regardless of how expectations are formed, agents will anticipate higher prices and this would push the user cost into negative territory, with a further increase in demand, and so on. Here we have a vicious cycle, a price bubble process, which can be rationalized even by a very simple model, with very general assumptions.

14 For a review of housing tax regimes in Europe, see Hilbers et al. (2008). See also ECB (2003) and Van den Noord (2005). By comparing the information in these papers with ours, it is possible to get a picture of how housing taxation has changed in the last 10 years.

15 Tax information refers to the 2009 tax codes reported in IBFD (2009). See also Borselli, Buoncompagni and Manestra (2010). 
From a theoretical point of view, under a comprehensive income tax, a fully neutral taxation of owner-occupation requires the taxation of imputed rents and capital gains on housing and the deductibility of mortgage interest (IMF, 2009, p. 17; see also Van den Noord and Heady, 2001, p. 30). Generally, tax systems are anything but neutral. Owner-occupation is tax-favoured with respect to renting in many countries, and with respect to most forms of return on personal savings. With only a few exceptions, imputed rents and capital gains on owner-occupied housing are not taxed; the tax relief on mortgage interest further reinforces the tax bias towards housing.

Table 1 shows that only Belgium and the Netherlands tax the imputed rent on owneroccupation. Mortgage interest costs attract tax relief in all countries except Germany and the UK. In the Netherlands, Belgium and the United States, interest expense is deductible from the tax base (but in Belgium the deduction is capped at a given amount of interest payments, whereas in the US refers to the amount of mortgage principal), so the tax advantage depends on the marginal tax rate of the owner. In the other countries the tax relief for financing costs mainly takes the form of a tax credit, often of limited duration. ${ }^{16}$ Finally, basically no country in our set taxes capital gains on owner-occupied housing.

Table 1. The taxation of owner-occupied houses in Europe and the US

\begin{tabular}{|c|c|c|c|}
\hline & $\begin{array}{l}\text { Taxation of } \\
\text { imputed rents }\end{array}$ & $\begin{array}{l}\text { Mortgage interest } \\
\text { tax relief }\end{array}$ & $\begin{array}{l}\text { Capital gains } \\
\text { taxation }\end{array}$ \\
\hline Belgium & YES & Tax deductibility with a limit & $\mathrm{NO}$ \\
\hline France & NO & $\begin{array}{l}\text { Tax credit for the first five years } \\
\text { with a limit }\end{array}$ & $\mathrm{NO}$ \\
\hline Germany & NO & $\mathrm{NO}$ & $\mathrm{NO}$ \\
\hline Ireland & NO & $\begin{array}{c}\text { Tax credit for the first seven } \\
\text { years with a limit }\end{array}$ & NO \\
\hline Italy & NO & Tax credit with a limit & NO \\
\hline Netherlands & YES & Tax deductibility without limit & NO \\
\hline Spain & NO & $\begin{array}{c}\text { Tax credit with a limit } \\
\text { on the amount of housing costs }\end{array}$ & NO \\
\hline UK & NO & NO & $\mathrm{NO}$ \\
\hline US & NO & $\begin{array}{c}\text { Tax deductibility with } \\
\text { a limit on the amount of } \\
\text { mortgage principal ( } \$ 1 \text { million) }\end{array}$ & $\begin{array}{c}\mathrm{NO} \\
(\text { if } \mathrm{CG}<\$ 500,000)\end{array}$ \\
\hline
\end{tabular}

Source: IBFD (2009)

To get an idea of the quantitative effects of the personal income tax rules concerning imputed income and mortgage interest, we compute the effective average tax rate on housing using a simplified version of the IMF methodology (IMF, 2009). ${ }^{17}$ Unlike the IMF, we do not consider

16 For example: in Spain the taxpayer is allowed to set off against his income tax liability 15 per cent of the costs incurred for acquisition or renovation of his primary residence, up to $€ 9,015$ (i.e. the maximum credit is $€ 1,352$ ); in Ireland, for first-time buyers, the relief - given at source with the effect of reducing the borrower's interest payments - takes the form of a tax credit at a rate of 25 per cent for years 1 and 2, 22.5 per cent for years 3, 4 and 5,20 per cent for years 6 and 7 (the interest relief is restricted to an interest payment of $€ 20,000$ for a couple); in France interest on loans for purchase or construction of a principal residence entitles the taxpayer to a 20 per cent tax credit for the initial 5 -year period of the loan ( 40 per cent for the first 12 months only), up to $€ 7,500$ per year for a couple (i.e. the maximum credit is $€ 3,000$ in the first year and $€ 1,500$ for the remaining four years); in Italy interest on mortgage loans taken to build or buy the principal residence is subject to a tax credit of 19 per cent up to $€ 4,000$ (i.e. maximum credit equal to $€ 760$ ).

17 The IMF methodology considers the purchase of a house at a predetermined price $(\$ 250,000)$, with a holding period of 10 years. The effective tax rate is computed as the ratio of the present value of all taxes paid during the holding period to the present value of house incomes; the yearly housing income is the sum of the imputed rent and the capital gains, assumed to be equal to 4 and 5 per cent of the house price, respectively. As in the IMF study, we use a 
property and transaction taxes, focusing only on the personal tax system. The results of these computations are shown in Figure 1.

In all the countries the personal tax system provides strong incentives to owner-occupation. Since the effective average tax rates are negative in all countries save Germany and UK, housing investment is subsidized by the personal income tax system. This is particularly true in the Netherlands and the US, where mortgage interest is deductible basically with no limit. Owneroccupation is tax-favoured de facto in Germany and the UK, since the effective average tax rate (equal to zero) is generally lower than the tax rates on alternative investments.

\subsection{Housing taxation and the financial crisis}

The main direct cause of the financial crisis lies in the bursting of the US housing bubble, so in assessing responsibility for the financial crisis it is natural to begin by examining the structure and the dynamics of the US housing market, particularly its demand side. The focus here is on the possible role of the "tax factor" in the recent US housing market dynamics. ${ }^{18}$

The IMF and the OECD do not consider tax rules as the main reason for the housing bubble: housing prices increased in countries with different tax systems and there were no tax breaks clear and big enough to explain the price dynamics that were observed (IMF, 2009; OECD, 2009). At the same time, many commentators have found fault especially with the tax treatment of housing capital gains and mortgage interest deductibility. Let us consider each of them in turn.

Figure 1. Effective average tax rates on owner-occupation (personal income tax)

\begin{tabular}{|c|c|c|c|c|c|c|c|c|}
\hline UK & Germany & Belgium & Italy & France & Spain & Ireland & $\begin{array}{c}\text { The } \\
\text { Netherlands }\end{array}$ & USA \\
\hline \multirow[t]{5}{*}{$0 \%$} & $0 \%$ & & & & & & & \\
\hline & & $-1.27 \%$ & $-1.37 \%$ & $-1.85 \%$ & $-2.44 \%$ & & & \\
\hline & & & & & & $-6.12 \%$ & & \\
\hline & & & & & & & & $-15.13 \%$ \\
\hline & & & & & & & $-19.31 \%$ & \\
\hline
\end{tabular}

\footnotetext{
Assumptions: mortgage fixed rate $=6 \%$; discount rate $=5 \%$; house value $=€ 500,000$; house price inflation $=5 \%$; imputed rent $=4 \% ; 80 \%$ debt financing; max PIT rate; no repayment of principal.

Source: our calculations

Data: IBFD (2009)

Methodology: IMF (2009).
}

mortgage interest rate of 6 per cent and a discount rate of 5 per cent; we also assume that the purchase is 80 per cent mortgage-financed. In contrast with the IMF study, the price of the house in our computations is set at $€ 500,000$; this permits the highest possible tax relief to be obtained with reference to all countries with a limited tax credit for interest.

18 For in-depth analyses of the dynamics of the US housing market, see Case and Shiller (2004), Glaeser, Gyourko, and Saks (2005), Himmelberg, Mayer, and Sinai (2005) and Shiller (2005). 


\subsubsection{Capital gains taxation}

Following the bursting of the US housing bubble, many commentators have argued that the housing policies pursued in the US over the last fifteen years or so are partly to blame for the financial crisis, particularly the policies aimed at increasing home ownership through access to mortgage loans for first-time buyers with low and variable incomes (see, for example, Kats, 2009). A tax measure in the same vein was the repeal of capital gains taxation on home selling with the Tax Relief Act of 1997 (henceforth TRA97).

TRA97 generated a change in the tax treatment of housing capital gains. Previously, housing capital gains had been taxed when homeowners sold their houses, unless they resorted to the "rollover rule" or to the "55-age rule". The roll-over rule allowed homeowners to postpone the taxation, provided they bought a house of equal or higher value within two years. The 55-age rule allowed sellers aged 55 or more to claim a one-time exclusion of $\$ 125,000$ against the capital gains tax. TRA97 abolished both rules and allowed homeowners to claim a $\$ 500,000$ exclusion $(\$ 250,000$ for singles) against the capital gain tax as often as every two years. It is worth noting that the ownership and use tests to claim the exclusion are not very strict, so it is often possible to get the tax benefit for a second home (Shan, 2008).

The repeal of capital gains taxation may have had an important impact on the effective taxation on housing. As an example, using the same IMF methodology and the same assumptions of Section 2.3, ${ }^{19}$ it can be demonstrated that following the TRA97 the effective average tax rate on housing could have decreased from $-6.37 \%$ to $-17.12 \% .{ }^{20}$ However, the overall effects of TRA97 on the US housing market are theoretically ambiguous ${ }^{21}$ and the existing empirical evidence does not offer clear-cut answers. ${ }^{22}$ Observing the time series of US house prices, something like a structural break appears to have occurred in the trend parameter between 1997 and 1998 (Figure 2). The date is revealing, according to some commentators, when one considers the repeal of capital gains taxation. In subsequent years, other factors became important: the rise in house prices, drawing investor attention; the end of the stock market boom following the peak in March 2000; the attempt by the Federal Reserve to avoid a severe recession in 2001 by pumping liquidity into the system; the public policies aimed at increasing the homeownership rate. However, according to some authors, the new provisions on capital gains taxation of 1997 may have contributed to the house price boom, "fuelling the mother of all housing bubbles" (Smith, 2007). ${ }^{23}$ These provisions may have acted as a precipitating factor, with effects that were then amplified by mechanisms involving investor confidence and expectations of market performance, apart from the other factors listed above. Adaptive or extrapolative expectations may have played a role in these amplification mechanisms (Shiller, 2005, p. 69; see also Section 2.2).

19 In the computations we use the highest marginal tax rate in 1996 and 1997 (39.6 per cent). The capital gains tax rate applied for 1996 is 28 per cent (see Shan, 2008).

20 The average tax rate in $1996,-6.37 \%$, is the mean between the tax rate for homeowners aged, at the time of selling, 55 years or more $(-8.23 \%)$ and less than 55 years $(-4.51 \%)$.

21 For example, TRA97 has also lowered all long-term capital gains tax rates; these tax rates were furtherly reduced in 2001 and 2003 (see Shan, 2008). The reduction of the capital gains tax rate with the TRA97 may have had effects on the market for rental properties, - where the rents are determined - affecting then indirectly the market of owneroccupied houses (see equation (1) in the text). The lower long term capital gains tax rates may have allowed to build rental projects in which landlords could break even also with lower rents. And lower rents could have eased the demand pressure on the market for owner-occupied houses, contrasting the possible demand pressure coming from the repeal of capital gains taxation on first-home selling.

22 See Bier, Maric, and Weizer (2000), Cunningham and Engelhardt (2008), Biehl and Hoyt (2008), Shan (2008) and Quayes (2010).

23 See also Bajaj and Leonhardt (2008) and Gjerstad and Smith (2009). 
Figure 2. S\&P/Case-Shiller Home Price Index 1980-2009

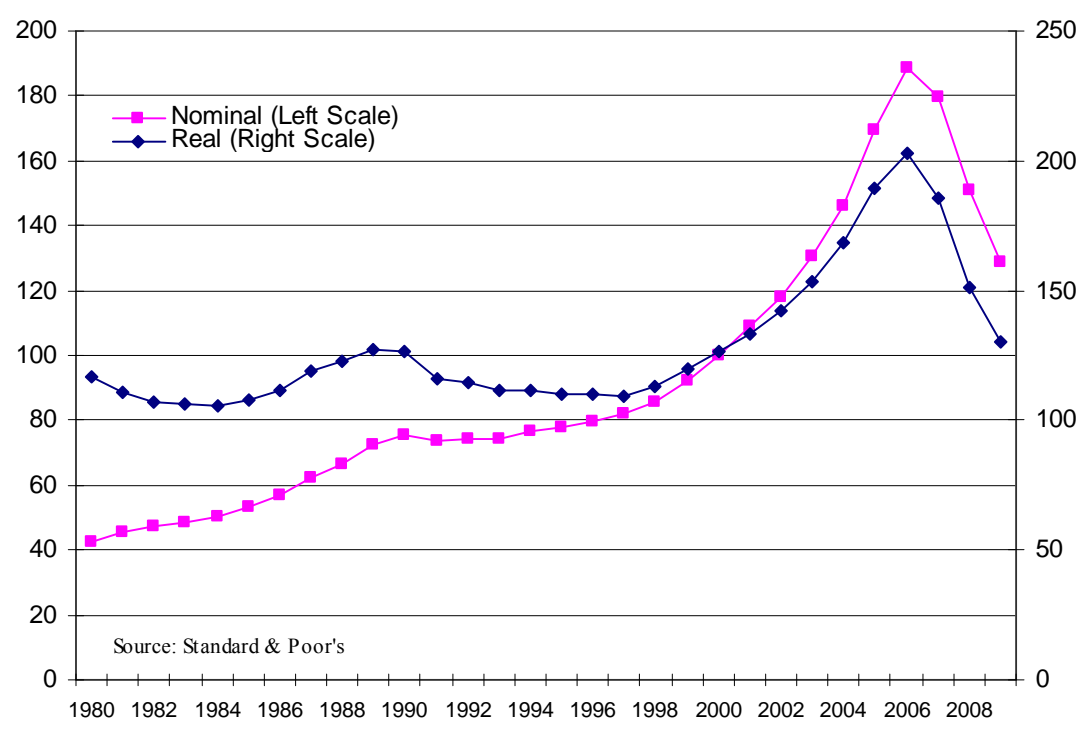

The importance of the repeal of the capital gains taxation in spawning the financial crisis is not undisputed. The IMF considers the role of the 1997 measures unclear, since the elimination of roll-over relief may have resulted in worse tax treatment for some taxpayers, and house prices did not increase everywhere, implying that other factors were at work (IMF, 2009). More importantly, perhaps, in analyzing the housing market dynamics many scholars assign no significant role in the price boom to the 1997 break (Case and Shiller, 2004, Glaeser, Gyourko, and Saks, 2005, Himmelberg, Mayer, and Sinai, 2005, and Shiller, 2005). ${ }^{24}$

\subsubsection{Mortgage interests deductibility}

In the US it is possible to deduct interest costs on mortgages taken to buy, build or improve a house (so called "home acquisition debt"), up to $\$ 1$ million. ${ }^{25}$

In general, mortgage interest deductibility, particularly when unlimited (as in the Netherlands) or with mostly non-binding limits (as in the US), by decreasing the cost of ownership, tends to tilt the households' decisions whether to rent or buy a house towards ownership; it also encourages people to spend too much on housing, and it may actually end up subsidizing wealthier homeowners, who have higher marginal tax rates, and the construction industry. ${ }^{26}$ Moreover, since the benefit is proportional to debt, the deduction is basically a subsidy to "gambles on housing" (Glaeser, 2009), and this could lead to excessive risk-taking. ${ }^{27}$

As for risk-taking, since the second half of the 1990s, credit scoring methods have been widely used in the US to price lending. Probably, this facilitated the access to credit for many highrisk borrowers. Obviously, for a given amount of debt, the riskier the borrower, the higher the interest rate paid and the greater the tax benefits from deduction. Unlike countries which generally

24 Burman (2008) argues that the new capital gains tax rules were unimportant with respect to the bubble, stressing that the previous rules raised little revenue.

25 Mortgage interest is an itemized deduction. In the US system, most taxpayers can elect to use itemized deductions or a standard deduction; the latter depends on the filing status of the taxpayer. In general, itemized deductions are chosen by wealthier taxpayers (Glaeser and Shapiro, 2002).

26 See Sullivan (2005) and Glaeser (2009).

27 Some argue that there may be positive externalities associated with homeownership and housing consumption that might be worth subsidizing through mortgage interest deductibility. But these externalities are very difficult to measure and, moreover, interest deductibility appears to have been ineffective in promoting homeownership in the US (see Glaeser and Shapiro, 2002 and the references therein). 
cap the deduction at a given amount of interest, the United States establishes the cap with reference to the mortgage principal, and this implies a clear tax favour to riskier borrowers. ${ }^{28}$

In contrast with other countries, in the US it is also possible to claim a deduction for interest on mortgage loans taken out for purposes other than house purchase, for example to buy a car or pay college tuition, up to $\$ 100,000$ (so-called home equity loans). ${ }^{29}$ Home equity - the difference between the market value of the house and the loans secured by the value of the house - can be used as collateral.

Home equity loans may have played a role in leading up to the financial crisis. In fact, the run-up in US housing prices, along with the rise in home acquisition debt fuelled by "bull" price expectations, may have directly fed the growth of home equity loans, thereby providing part of the mortgage raw materials for the strong growth of the securitization industry. This process may have been amplified by the deductibility of mortgage interest.

The deductibility of interest on home equity loans clearly creates a bias to personal debt, encouraging people to prefer borrowing against home equity to other forms of borrowing, and to extract the equity from their home for personal and business reasons.

The lowering over time of personal income tax rates in the US has reduced the size of the benefit stemming from the deductibility of interest expense (Poterba, 1992), which nevertheless remains substantial by international standards. And when the international comparison refers not only to interest tax relief, but also to the taxation of imputed rents and taxes on capital gains, ownership and transactions, the US remains in the set of countries with low housing taxation (see Section 2.3 above and IMF, 2009, p. 20).

The role of tax deductibility alone with respect to the recent bubble is unclear because of conflicting evidence. Considering our set of countries (see Section 2.3), it is true that the Netherlands, the other country with strong interest deductibility and providing substantial tax benefits according to our computations, belongs to the "fast lane" set of countries, according to the IMF ranking based on the house price increases in the last 20 years (Hilbers et al., 2008). On the other hand, the UK too was a "fast lane" country basically without having provision for any interest tax relief for most of the recent boom period. ${ }^{30}$ More importantly, as far as the US is concerned, there was no change in the tax relief for interest expense to explain the housing boom; moreover, the price dynamics in the US differed across states and regions although there are no interstate differences in interest deductibility.

A possible indirect role of interest deductibility in the US housing market dynamics may be related to the large increase in low- and no-downpayment mortgages during the second part of the price boom period, ${ }^{31}$ which were probably facilitated by the housing policies enacted in 2004 and subsequent years. ${ }^{32}$ Given the asymmetric treatment of personal debt and equity, the decrease of mortgage downpayments may have given rise indirectly to a tax break. Since the cost of personal

28 The same holds true in countries where there are no limits to interest deductibility (e.g. the Netherlands).

29 In the Netherlands it was possible to claim interest deductions on equity withdrawals until 1996.

30 The UK phased out interests deductibility over the period 1974-1999. First, a ceiling on the mortgage principal eligible for deduction was introduced. Then, the rate at which it was possible to claim the deduction was gradually lowered to zero (OECD, 2000, p. 151).

31 According to the surveys conducted by the National Association of Realtors, in 2003 the median downpayment for first-time homebuyers was equal to 6 per cent, a figure which fell to 2 per cent in the period 2004-2007. The median downpayment for repeat homebuyers also declined starting in 2004, though to a lesser extent (see www.realtor.org).

32 On 16 December 2003 the American Dream Downpayment Act was signed into law with a view to assisting lowincome first-time homebuyers by providing downpayment. Among other things, the Act expanded the supply of nodownpayment mortgages for first-time homebuyers (US Department of Housing and Urban Development, 2005). See the White House press release, President George W. Bush, "Increasing affordable housing and expanding home ownership", 2 September 2004. 
housing debt is deductible, unlike the opportunity cost of housing equity, the consequence of no- or lower downpayment mortgages may have been an abrupt fall in the user cost of housing. ${ }^{33}$

Despite the inconclusive evidence based on simple time series and cross-section comparisons, many observers think that the interest tax relief may have contributed to house price inflation in the US, and so to the financial crisis, ${ }^{34}$ along the lines of a catalyst in a chemical reaction. The simple and very general economic model sketched in Section 2.2 predicts that tax breaks of the kind provided in the US can contribute to the volatility of the housing market; and that mortgage interest tax relief can be a factor of instability if it is coupled with low financing costs and/or "exuberant" house price expectations.

\section{Performance-based remuneration and taxes}

\subsection{Stock options}

It is generally acknowledged that equity-based and other performance-related compensation plans at large financial institutions were one of the factors that led to ever great risk-taking and thus contributed to the financial crisis that began in 2007.

The last two decades have seen an enormous rise in executive remuneration. In the United States, between 1990 and 2008 the average pay of the chief executive office (CEO) of a large corporation rose from 100 to nearly 400 times that of the average worker. A similar though less marked pattern can be found in Europe. The chief factors responsible for this huge gap are the various forms of performance-based compensation, most notably bonuses and stock options.

Finance began influencing firms' governance in the early 1990s. The idea of creating "shareholder value" rested on the assumption that markets could evaluate executives' performances better than human judgement. Various forms of stock-based compensation became very popular, first in the United States and then in other developed countries, on the theory that they could motivate employees to act in the interest of the firm's shareholders and align the interests of senior executives with the general interest of the firm. Many large firms paid a significant portion of total compensation in stock or similar instruments, with the stock-based portion typically greater, the higher the position of the employee. The increased use of stock-based remuneration gave rise to ever great incentives to risk-taking that were not counterbalanced by employees' exposure to losses in the event of poor corporate performance, since other factors were in place. In fact, although vesting and other restrictions required employees to hold some newly granted stock for significant periods of time, the sensitivity of equity prices to short-term corporate performance and shareholders' frequent tendency to focus on short-term results spurred employees, and especially executives, to aim at maximizing stock-price increases in the short-term rather than the firm's longterm growth. ${ }^{35}$ The same factors also led employees to underestimate possible future downside risks.

33 As an example, using the highest marginal tax rate of the federal income tax in 2003 and 2004 (35 per cent) and assuming a downpayment equal to 5 per cent in 2003 and 0 per cent in 2004, the effective average tax rate computed with the IMF methodology (see Section 2.3) would decrease from -17.97 to -18.92 per cent. Since the reduction of downpayments referred especially to low-income first-time buyers, it is reasonable to compute the change in the effective taxation also with the lowest income tax rate (10 per cent); in this case the effective average tax rate would decrease from -5.13 to -5.41 per cent. Of course, it is hard to say if and to what extent these changes in the economic advantageousness of housing investment may have been statistically significant at the margin for housing market dynamics.

34 See, for example, Sullivan (2008) and Surowiecki (2009).

35 Financial Stability Forum (2009). The theoretical literature has tried to explain the shortcomings of stock options in terms of the information asymmetries between managers and shareholders. In this view, stock options are a form of managerial "rent-extraction" from the firm at the expense of shareholders: the assumption here is that executive compensation programmes are usually developed by insiders (the executives themselves) rather than by 
The incentive to risk-taking arising from stock-based remuneration was particularly strong in the financial sector. Given the structure of financial markets in most developed countries, banks and other financial firms can change their desired mix of risk/return much more easily and quickly than non-financial firms. For financial firms, then, large bonuses linked mainly to short-term profits regardless of the possible long-term risks may have induced managers to choose an ever-higher level of risk in order to achieve higher returns, leading to the systemic excessive risk-taking that severely threatened the global financial system.

Compensation practices at large financial institutions have generally been counted as one of the sources of the system of distorted incentives that led to the financial crisis. Here the question is: did tax rules favour remuneration schemes that rewarded high risk-taking or focused on short-term performance?

It is a common belief that stock options and other stock-based forms of remuneration are taxfavoured compared with cash compensation. If this is true, then the tax system could be held responsible for contributing to the crisis through its pro-cyclical effects by reinforcing a structure of incentives that led to excessive risk-taking.

Stock options are financial instruments that give the owner (usually the firm's executives and other employees) the right to buy a certain asset (usually the company's shares) at a specified price (strike price or exercise price) at any time during a predetermined period or at the end of that period. Over the life of a stock option four different events can be identified: grant, when the stock option right is granted to employees; vesting, the expiring of the minimum holding period required to exercise the option (usually 3 to 5 years); exercise, when the employee actually exercises the option right and gets the stock, disposal, the sale of the shares received through option exercise. ${ }^{36}$

The tax treatment of stock options is linked to a number of issues, such as the qualification of income (employment income or capital income), the applicable taxes and charges (income tax, capital gains tax and social security contributions), the timing of taxation (grant, exercise or disposal of shares) and the treatment at corporate level (whether or not the cost can be deducted from corporate income). As a benchmark we assume a tax treatment that ensures neutrality between stock options and cash salary, which would require equal treatment of the two forms of remuneration at personal level and the deductibility of stock option costs from corporate tax (OECD, 2005). ${ }^{37}$

Given that benchmark, cross-country analysis of the tax treatment of stock options offers a mixed picture. According to an OECD study carried out in 2005 using legislation in force in 2002, tax rules vary substantially from country to country, but in most cases stock options enjoy only limited benefits compared with cash salary. Since stock options are considered a form of deferred compensation, in most OECD countries their benefits are treated as ordinary income for employees and taxed at progressive income tax rates. Taxation is usually applied at the time of exercise. The tax base is the increase in stock value accrued until exercise, i.e. the difference between the market price of the shares at the exercise date and the strike price. By contrast, the subsequent gain arising from disposal of the shares, i.e. the difference between the selling price and the market price of the shares at the exercise date, is usually taxed at the capital gains tax rates (but is exempt in countries where capital gains are not taxed).

Under given conditions (so-called concessionary schemes) stock options enjoy a preferential tax treatment at the employee level. The preferential treatment may consist in the possibility of

shareholders and will thus reflect executives' preferences. In this reading, stock options contribute to the corporate governance problems instead of solving them. See OECD (2005).

36 See OECD (2005).

37 This neutrality condition also applies under uncertainty if taxation takes place at exercise or applies at grant on the basis of the option's fair market value. 
deferring taxation until the disposal of the shares (Canada, Denmark, France, Iceland, Ireland, Italy, Slovak Republic, the UK and the US) and/or in tax rate reductions. The latter often consist in the lower capital gains tax rates being applied not only to the gain accruing after exercise, but also to previous gains arising between the grant date and the exercise date, which would otherwise be taxed as ordinary income (Denmark, Iceland, Ireland, Italy, Japan, Spain, the UK and the US). Other countries give tax relief in determining the tax base. ${ }^{38}$ In many countries (including Denmark, France, Ireland, Italy, Japan, Spain, the UK and the US) preferential regimes also include exemption from social security contributions. ${ }^{39}$

At corporate level, stock options usually give the right to a tax deduction on the difference between the market price of the shares at the exercise date and the strike price, i.e. for an amount exactly mirroring that taxed as personal income for the employee. In many countries (Denmark, Germany, Greece, Iceland, Luxembourg, the Netherlands, Portugal, Sweden, Switzerland, Turkey, the UK and the US) the deduction is granted, at least for some plans, even if the firm has not incurred an actual cash outflow (i.e. when employees are given newly-issued shares). In others (including France, Italy, Japan, Spain, and the US) or for some plans, the economic cost of stock options (the dilution in stock value when newly-issued shares are assigned to employees) is a nondeductible item. Finally, in some countries (Austria, Belgium, Hungary, Ireland, New Zealand, Poland and the Slovak Republic) deduction of stock option costs is never allowed. Consequently, from the point of view of companies, stock options can be tax-disadvantaged compared with cash salary.

Each country can provide for a different combination of employee and employer tax treatment of stock option plans, depending on the specific characteristics of the plans, i.e. on whether or not they fulfil the requirements of concessionary schemes. As a result, different tax provisions can combine in a number of ways in each country, giving rise to an overall tax wedge on stock option benefits that can vary from plan to plan.

The OECD report calculates marginal tax wedges on the different types of stock option plans in OECD countries and compares them with tax wedges on ordinary salary. The calculation takes into account both employee- and employer-level taxation and social security contributions. The results show that in some countries (e.g., Australia, Austria, Canada and Japan) the tax wedge on stock options, at least for certain schemes, is greater than that on ordinary salary. In many countries (e.g., Germany, Luxembourg, Sweden, Switzerland and Turkey) the tax treatment of stock options and cash salary is the same and so are the effective tax rates both for average and higher levels of income. In some cases (including Denmark, Greece, Italy, the UK and the US) neutrality between stock options and ordinary salary obtains only for schemes for which deductibility from the corporate income tax base is allowed.

Under certain conditions or for certain schemes, a number of countries (including Australia, Canada, Denmark, France, Italy, Japan, Korea, Portugal, Spain, and the UK) grant preferential tax treatment of stock options at the personal level while also allowing deductibility at the corporate level. In these countries, stock options are tax favoured compared with ordinary salary; often, the tax advantage of stock options increases with income. For high-income taxpayers, the tax advantage seems especially great for certain concessionary schemes in Belgium (more than 22 percentage points), Denmark (58.5 points), France (26.5), Italy (42.8), Spain (48.9) and the UK (30). ${ }^{40}$

\footnotetext{
38 For example, in Austria a part of the gain (up to 50 per cent) is exempt; in Canada and in Spain the taxable base is respectively 50 and 70 per cent of the employee benefit. In Luxembourg the employee benefit is reduced for tax purposes by 5 per cent each year (up to a maximum of 20 per cent).

39 Some countries also exempt stock option benefits arising from standard plans from employee and employer social security contributions.

40 OECD (2005), Table 2.7, pp. 73-76.
} 
Other countries (e.g., Canada, Finland, Japan, Spain and the US) combine a preferential tax treatment at the employee level with non-deductibility at corporate level. Depending on individual cases, the tax wedge on stock options can be higher or lower than that on ordinary salary. However, at high levels of income, stock options tend to be tax-favoured in these countries.

Although preferential tax treatment of stock option benefits can dramatically lower the tax burden on equity-based remuneration, the importance of tax advantages is often limited by the conditions that must be fulfilled in order to allow the benefits. For example, in order to enjoy preferential tax treatment, the employee has to hold the shares for some time after exercise (at least one year in the US); in addition, the concessionary schemes quite often cap the amount of stock option benefits that can enjoy the favourable tax treatment. ${ }^{41}$ Although these caps are sometimes high, in conjunction with other conditions they often result in concessionary plans being used mainly by start-up firms or in limited cases.

In the light of the foregoing facts and considering the more neutral or even disadvantaged tax treatment of standard stock option plans compared with ordinary salary, the common belief that stock options enjoy a tax advantage over cash-based remuneration is not confirmed in general. On the contrary, Fehr, Knoll, and Mikus (2004), based on a comparison of the relative tax treatment of cash-based and standard stock option compensation plans in the US, the UK Germany and France, show that the latter are often tax-disadvantaged; ${ }^{42}$ a tax preference for stock options only arises from large differences between personal and capital gains tax rates (as in France) or from tax discrimination of cash compensation (as in the US).

The empirical evidence on the supposed tax preference of stock options, mostly referring to the United States, is also mixed (OECD, 2005). Some studies (e.g., Hall and Murphy, 2003) argue that the widespread use of stock-option plans in the US during the 1990s can be partly explained by a combination of tax and accounting rules. Hall and Liebman (2000), examining the relative tax treatment of stock options and cash salary in the US in the 1980s and 1990s, find only a moderate tax advantage of "non-qualified stock options" over salary, because the tax advantages to the executives of deferring taxes until exercise were largely offset by the tax disadvantages to the company of not being able to deduct option expenses from taxable profits until the time of exercise. ${ }^{43}$ In general, however, they find little evidence that changes in the tax treatment of stock options during the 1980s and the 1990s have played a major role in the dramatic explosion of executive stock option pay. Other factors (such as changes in corporate governance) appear to have had more influence.

In spite of the controversial results of economic analysis and the inconclusive empirical evidence, it is nonetheless possible that tax considerations actually do play a role in the choice between ordinary salary and stock options. For instance, stock options could be tax-preferred to cash remuneration from a unilateral perspective, i.e. on the basis of solely employee or employer taxation: in given circumstances, one of the two levels of taxation could dominate the other in the determination of remuneration policies. This could happen, for instance, because of shortcomings in the corporate governance mechanisms regulating the firm's remuneration policies. In the case of large, widely held corporations, it is quite likely that executives' remuneration policies are decided by executives themselves, since boards tend to be dominated by CEOs and senior executives of

41 For instance, under the UK concessionary scheme known as the Company Share Option Plan, the total value of shares an employee can receive under option must not exceed $£ 30,000$. Another UK concessionary scheme, the Enterprise Management Incentive option, is targeted to companies with gross assets of less than $£ 30$ million, and provides for a maximum of $£ 100,000$ stock option benefit to each employee. In the US, the preferential treatment for Incentive Stock Options is subject, among other conditions, to the value of the shares underlying stock option benefits not exceeding $\$ 100,000$.

42 Like the OECD, this study considers both employee- and firm-level taxation.

43 They found also a moderate advantage of non-qualified stock options over incentive stock options (ISOs), due to the fact that option expenses cannot be deducted for ISOs. 
other firms rather than by individual shareholders. These board members have an interest in keeping executive compensation high. Under these circumstances, it is very likely that employees' taxes outweigh corporate tax considerations. ${ }^{44}$ An alternative explanation, put forward by some studies (Murphy, 2002; Hall and Murphy, 2003) could be that decisions over stock option grants are made on the basis of the "perceived cost" rather that the real economic cost of the options. The "perceived cost" of an option is lower than the economic cost, because it only takes into account the actual cash flow for the firm and not the opportunity cost, equal to what an outside investor would pay for the option (OECD, 2005). Finally, in some countries tax incentives to use stock options instead of ordinary salary may arise from specific features of the tax system or from the interaction between tax law and other rules, and not just from the tax treatment of stock options. ${ }^{45}$

The US offers the chief example of interaction between tax and other rules. As with other countries, analysis of the general tax treatment of stock option plans in the US does not reveal a general tax bias in their favour (see box).

\section{The Tax Treatment of Employee Stock Options in the US}

The US tax code provides for two possible tax treatments of stock options:

1) In the case of standard stock option plans, referred to as non-qualified stock options (NQOs), employees are taxed at the exercise date and at personal progressive rates on the difference between the market value at the same date and the exercise price. Any subsequent gain realized upon sale of the shares is taxed at the lower capital gains rates. ${ }^{46}$ As far as the employer is concerned, NQOs have the advantage of allowing a tax deduction at the same time and in the same amount as the ordinary compensation paid to the employee, even when there is no actual cost to the firm (unlike cash remuneration);

2) If stock option plans satisfy given criteria, set out by the tax code, they are called incentive stock options (ISOs). ${ }^{47}$ ISOs allow employees to defer taxation on the gain emerging at the exercise date until the stock is sold and have it taxed at the lower capital gains rates ${ }^{48}$. On the other hand, the employer gets no tax deduction for ISOs.

For both types of plan, there is scarcely any tax favour by comparison with cash-based remuneration. In fact, the only tax advantage of NQOs may consist in the possibility of a corporate tax deduction even if there is no actual cash outflow. For the employee, apart from the deferment of taxation from grant to the exercise date, NQOs do not have any particular tax advantage over cash remuneration, except where the employee does not sell the shares immediately after exercise, since all subsequent gains are taxed at the lower capital gains tax rates. On the other hand, under ISOs employees are taxed on their stock option income at the lower capital gains tax rates, but at the same time companies forfeit their stock option corporate deductions.

Taking into account both employee and employer tax considerations, ISOs are preferred to NQOs if under the latter the additional taxation on the employee exceeds the value of the deduction to the employer. For employees facing high personal tax rates, ISOs may be better

44 Smith and Huston (2009) find that individual-level tax incentives also outweigh corporate tax incentives in employees' decisions whether to sell the shares immediately after exercise or to hold them in view of future price increases.

45 Another potentially important issue is cross-country option ownership. Many executives and other highly qualified employees paid with stock options transfer their tax domicile to low-tax countries during the holding period. This enables them to reduce their tax burden even if the tax rules of the employer's country do not provide for a favourable tax treatment of stock options.

46 Provided the shares are held for at least one year after exercise.

47 Section 422 of the Internal Revenue Code. Stock obtained under an ISO cannot be disposed of within two years of the grant date nor within 12 months after exercise. ISOs cannot be granted with an exercise price below the stock price at grant date, and the aggregate stock value covered by the ISOs is limited to $\$ 100,000$ per year per employee.

48 Both benefits are allowed provided that the shares are held for at least one year after exercise. If the employee sells the shares before that period, ordinary personal tax rates apply. 
than NQOs in the case of companies with low tax rates, such as start-ups or companies with net operating losses. ${ }^{49}$ Start-ups, with low taxable profits, tend to use ISOs, as they would face liquidity constraints if they had to pay high salaries to attract executives and other highly qualified employees. On the other hand, since the value of their stock may increase dramatically over time, the use of incentive stock option plans is quite common. ${ }^{50}$ In short, in the case of ISOs, employee tax considerations tend to predominate. By contrast, in the case of NQOs, used mostly by large, profitable companies, especially for senior executive compensation packages, since the tax advantage depends on the value of the shares at the exercise date and on the company tax rate, company tax considerations tend to prevail. $^{51}$

While the tax advantage for employees may help explain the large use of ISOs in start-up companies, to understand the widespread use of NQOs in large companies ${ }^{52}$ other tax factors and a combination of tax and accounting rules must be taken into account. First, in 1993 a powerful incentive came from the newly enacted rule that introduced a $\$ 1$ million cap on "non-performancebased" compensation that a corporation could deduct from its taxes, since the cap did not apply to stock option plans. And until 2004, US accounting rules allowed companies to issue stock options to employees and, unlike any other type of compensation, report a zero compensation expense on their books. ${ }^{53}$ Moreover, since 1969 the US tax code (Section 83) allows corporations issuing NQOs to deduct from their taxable income, on the exercise date, the difference between what the employee paid to exercise the option and the market value of the stock received. This amount exactly mirrors the amount that is taxed as personal income of the employee. This combination of accounting rules permitting corporations to grant huge NQOs "free of charge", i.e. without having to register any cost in their financial accounts, and tax rules allowing corporations to deduct the stock option income of the employee in the year of exercise, even when there was no actual cost to the firm (as in the case of newly-issued shares), gave companies an incentive to issue huge stock option grants, because stock options made possible large tax deduction that could dramatically lower their taxes without affecting the profits shown on their books. ${ }^{54}$

49 Although the possibility of corporate deduction linked to NQOs may have a value for corporations with net operating losses, since the US tax code allows them to carry the losses back (for two years) or forward (for up to 20), for these corporations the relative weight of the corporate tax deductibility of stock option costs is likely to be lower, in practice, than the favourable employee tax treatment.

50 In the context of venture capital, stock options have been often used to overcome capital and liquidity constraints. The foreseeable increase in value of stock options on the shares of young, high-growth companies creates incentives not only for executives, but also for other qualified employees, to work for such companies even if the cash salaries are less attractive than those offered by larger companies. This argument has found empirical support, and has often been used by policymakers to justify tax policies that allow for a favourable tax treatment of stock options in the context of venture capital-financed firms. However, in many cases tax incentives have been ill-focused, making benefits available to a much greater number of entities than those actually suffering from liquidity constraints.

51 Empirical evidence on the role of taxes in the choice between ISOs and NQOs is somewhat mixed. On an aggregate level, over time the relative use of ISOs and NQOs has changed consistently with changes in the personal, corporate and capital gains rates. Hite and Long (1982) show that firms switched from ISOs to NQOs after the Tax Reform Act of 1969 lowered the top rates for individuals. However, Madeo and Omer (1994) report that firms that switched from ISOs to NQOs following the 1969 tax reform tended to have low tax rates, whereas in theory it should have been the high-tax firms switching. Balsam, Halperin, and Mozes (1997) report that after the Tax Reform Act of 1986 NQO usage increased relative to ISOs because the top individual rate was set below the top corporate rate, and the capital gains rate was set equal to the tax rate on ordinary income.

52 Jaquette, Knittel, and Russo (2003) estimate that in the late 1990s and early 2000s 89 per cent of options granted in the United States where NQOs.

53 This happened so long as, on the grant date, the stock options were "at the money", i.e. their exercise price was not lower than the stock price at grant date. More precisely, since 1973 companies could avoid recording any expense on granted options in their financial statements. However, from 1995 onwards they had to disclose the use of stock options and options' fair value in the notes to their financial statements. See Bulow and Shoven (2005).

54 The lack of a requirement to report stock option expenses in companies' financial statements probably also helps explain the fraudulent practice of "backdating" stock options that many companies resorted to in the 1990s and early 2000s according to investigations by the Securities and Exchange Commission. Executives were awarded stock 
In 2005, in the wake of huge corporate financial scandals such as Enron and WorldCom, not to mention the dot-com tech boom and subsequent bust, a new Financial Accounting Standard (FAS 123R) issued by the Financial Accounting Standards Board (FASB) became mandatory for all publicly traded corporations. FAS $123 \mathrm{R}$ requires all companies to record a compensation expense equal to the fair value on grant date of all stock options provided to an employee in exchange for the employee's services. ${ }^{55}$ Thus, since 2005 accounting rules require companies to expense stock options at the grant date, ${ }^{56}$ while tax rules still allow deduction of stock option expenses at the exercise date. Although the gap has been reduced and there is some evidence of a shift from stock options to restricted stock in large firms' compensation plans ${ }^{57}$ (Carter, Lynch, and Tuna, 2007), the accounting incentives to grant large high stock option benefits to executives are still large, particularly when stock prices are rising. ${ }^{58}$ On the other hand, given the current mismatch between accounting and tax rules, stock options which are granted and vested but never exercised by the holder (e.g. in case of subsequent price drop) produce a corporate book expense but no tax deduction. ${ }^{59}$ Overall, then, the current US tax and accounting rules tend to have pro-cyclical effects.

The wave of corporate financial scandals in which executives received huge amounts through the exercise of stock options prompted a revision of stock option regulations aimed at making remuneration policies more transparent, improving the structure of incentives for managers so as to reduce excessive risk-taking, and reducing inequalities between different classes of employees. In April 2009, in the wake of action to counter the main factors responsible for the 2007-2008 financial crisis, the Financial Stability Forum - FSF (now Financial Stability Board - FSB) released a set of Principles for Sound Compensation Practices ${ }^{60}$ meant to apply to significant financial institutions, especially large, systemically important ones and aimed at reducing incentives to excessive risk-taking that may arise from the structure of compensation schemes. In this approach, compensation regimes must be viewed in the broader context of sound corporate governance and effective risk management; implementation of the principles at national level will ensure that compensation structures are consistent with firms' long-term goals and prudent risk-taking. ${ }^{61}$ Similar principles have been endorsed by the European Commission. ${ }^{62}$

options backdated to a point at which the company's stock prices were lower, so that the exercise price could be set at a lower level.

55 The International Accounting Standard Board (IASB) implemented a similar approach effective 1 January 2005.

56 The fair value is amortized over the vesting period. That is, compensation expense is recognized prior to the tax deduction (which arises when the employee exercises the NQO), generating a temporary difference and thus a deferred tax asset in each year of the vesting period (Scholes et al., 2008).

57 Restricted stock grants are equivalent to call options with an exercise price of zero. Unlike stock options, they have always had to be reported on companies' financial statements, thereby reducing corporate net income at year's end.

58 Data from tax returns of US companies for tax years 2004-2007 show that stock option compensation expenses permitted companies huge tax savings and were one of the chief factors in the difference between book and tax income reported by US corporations. The bulk of this difference was concentrated in a relatively small number of corporations that awarded substantial stock options to their executives. See Levin (2009).

59 Only if a stock option never vests can previously booked expenses be recovered. See Levin (2009).

60 Financial Stability Forum (2009).

61 The FSF principles identify several lines of action aimed at ensuring that compensation structures are consistent with firm's long-term goals and prudent risk-taking. Specifically, firms' boards of directors must play an active role in the design, operation and evaluation of compensation schemes. Compensation, particularly bonuses, must properly reflect risk; and the timing and composition of payments must be sensitive to the time horizon of risks. Stakeholders, including shareholders, should be adequately and timely informed on compensation policies in order to exercise effective monitoring; an annual non-binding shareholder advisory vote on executive compensation is also recommended. For their part, regulators will have to assess firms' compensation policies as part of the overall assessment of their soundness. Finally, with regard to risk management, the FSF identified three key principles. First, compensation must be symmetric with risk, linking the size of the bonus pool to the overall performance of the firm; employees' incentive payments should be linked to the contribution of the individual and business unit to such performance. Bonuses should diminish or disappear in the event of poor firm, divisional or business unit performance. Second, compensation payout schedules must be sensitive to the time horizon of risks: payments should not be finalized over short periods where risks are realized over long. Third, the mix of cash, equity and other 
Although neither the FSB nor the European Commission mentioned tax rules among the reforms needed to discourage remuneration practices that lead to excessive risk-taking, at national level the tax treatment of bonuses and stock options have became part of this debate. In the United States, changes to the combination of accounting and tax rules that distort firms' choices between stock options, other forms of equity-based compensation and ordinary salary have been under discussion for several years. During the Bush Administration, the Senate Finance Committee examined a number of bills to raise the taxation of stock options and private equity managers' remuneration. Similar proposals have been presented since President Obama took office. ${ }^{63}$ Up to now, however, none of these proposals has been approved. Some limited measures have been adopted in connection with the crisis. The Emergency Economic Stabilization Act (EESA) of 2008 tightened the tax rules for non-qualified deferred compensation schemes involving tax-exempt foreign vehicles ${ }^{64}$ and restricted the deductibility of executive compensation for financial institutions selling troubled assets to the Treasury. ${ }^{65}$

In Europe, the May 2008 EU Council of Economic and Finance Ministers condemned overly generous pay and benefit packages for corporate executives and cited changes to preferential tax rules as one of the possible tools to address the issue. Since then, some limited measures have been taken at national level. In 2008 Italy repealed the favourable stock option rules providing for lower capital gains taxation (12.5 per cent) at disposal of the whole gain accrued since grant; the lower capital gain tax rate is now only applied for the taxation of the gain accrued between exercise and disposal, while previously accrued gains (i.e. between grant and exercise) are now once again subject to ordinary income tax. ${ }^{66}$ In 2009 Austria repealed the partial tax exemption available under a concessionary scheme for stock options benefits not exceeding $€ 36,400$ at the time of grant. Denmark also abolished one of the concessionary stock option schemes. The Netherlands enacted new tax rules on "excessive remuneration schemes" leading to the application of progressive personal income tax to many forms of deferred compensation. However, it is unclear whether these limited restrictions of stock option concessionary schemes are aimed at tightening the rules on executives pay or instead reflect national budgetary needs.

forms of compensation should be consistent with risk alignment. The mix is likely to differ across employees and to involve a smaller cash component the more senior the employee. The FSF Principles for Sound Compensation Practices were followed on 25 September 2009 by a set of Implementation Standards that identify specific proposals in key areas, such as corporate governance reforms, global standards on pay structure and greater disclosure and transparency. In March 2010, the first Peer Review Report on compensation prepared by the FSB found significant changes in regulatory and supervisory frameworks in FSB member states to implement the Principles and Standards, as well as progress in implementation by significant financial institutions. However, the Report also found differences in the approach to and pace of implementation; further, while significant progress had been achieved in the areas of governance, establishing supervisory oversight and promoting disclosure of compensation, further work needed to be done to raise standards of risk adjustment of pay structures across the industry.

62 See European Commission (2009a and 2009b).

63 See, for example, the bill filed in July 2009 by Senator C. Levin: Ending Excessive Corporate Deductions for Stock Options Act (Levin, 2009).

64 The new section 457A added to the Internal Revenue Code requires non-qualified deferred compensation paid by a non-qualified entity (i.e. a non-resident tax-transparent vehicle) to be taxed as part of the recipient's income as soon as there is no longer a substantial risk of forfeiture. The provision was introduced mainly as a response to perceived abuses by hedge funds. Under previous legislation, the deferred compensation was taxed only in the year of receipt, and not in the year it was earned. In addition to the immediate taxation, a penalty tax of 20 per cent of the deferred compensation has also become payable.

65 As part of the Troubled Assets Relief Program (TARP) enacted in the Emergency Economic Stabilization Act of 2008, Congress tightened existing rules on the tax treatment of executive compensation and golden parachute payments made by financial institutions that sell troubled assets to the Treasury as part of the TARP. For institutions selling more than $\$ 300$ million in troubled assets, the existing $\$ 1$ million limit on the deductibility of nonperformance-based compensation paid to the five most highly compensated employees (including the CEO) was reduced to $\$ 500,000$.

66 At the same time, a specific tax exemption for investments in start-ups was introduced. 
A more explicit link to the distortions arising from remuneration policies in the financial sector seems to have inspired the temporary bonus taxes introduced between the end of 2009 and the beginning of 2010 by some European governments. At the end of 2009 the UK and France introduced a one-off tax on discretionary bonuses in the banking sector, aimed at encouraging change in the remuneration practices that had contributed to excessive risk-taking and at developing sustainable long-term remuneration policies that take greater account of risk and facilitate the buildup of loss-absorbing capital. ${ }^{67}$ In both countries stock option plans were excluded from the tax, provided their structure allowed sufficient links to medium-term corporate perfomance. The tax was intended as a temporary measure paving the way for better remuneration policies. In both governments' view, in the longer term remuneration practices should change as a result of corporate governance and regulatory reforms. Another purpose of the tax was to recover part of the government subsidies paid to financial institutions and to prevent government-financed banks from paying excessive remuneration while they still needed to strengthen their capital base. A similar initiative has been taken by Portugal, with the introduction of a 50 per cent "punitive tax" on bonuses paid in 2010 to managers and board directors of financial sector institutions. ${ }^{68}$

In 2010 Italy, where banks had not received government subsidies, introduced a 10 per cent surcharge on stock options and variable bonuses paid to financial sector CEOs and directors. However, unlike the British and French measures, the Italian levy, which applies to variable remuneration exceeding three times fixed earnings, is permanent and also applies to stock options. ${ }^{69}$

The measures on the taxation of bonuses are part of the wider debate about the possible remedies to the crisis and about who should bear the cost of past bailouts or future bank failures. At the international level, both the IMF and the European Commission have analyzed two possible forms of financial sector taxation: a financial activity tax applied to the value added of the banking and financial sector, and a stability levy, a tax on some balance-sheet items of banks and other financial institutions, possibly used to finance a special anti-crisis fund. Several countries (including the US, ${ }^{70}$ UK, France, Germany and Sweden) have already introduced or are introducing stability levies. A penalty tax on bank bonuses is often considered an appropriate supplementary measure. However, the temporary levies on bonuses have proved to be of limited effectiveness: in most cases banks and financial institutions have preferred to bear all or part of the cost of the tax, leaving the net amount of bonuses almost unaffected. In some cases, banks active at the international level have chosen to spread the cost of the tax over all employees, not just those in the countries directly affected by the levy.

In conclusion, although analysis of the tax treatment of employee stock option plans, made taking into account both employee and employer level taxes, does not confirm a general tax preference for stock option plans over cash remuneration, it is possible that a tax-preference for stock option plans has emerged as a consequence of the favourable tax treatment at employee level outweighing corporate tax considerations (or vice versa). In addition, in some countries, notably the

67 The one-off tax only applies to bonuses paid in 2009 in the case of France, and to bonuses paid between 9 December 2009 and 5 April 2010 for the UK. In both countries the tax rate is 50 per cent and stock options are excluded from the tax base. In the UK the tax applies to bonuses exceeding $£ 25,000$; in France the exempt amount is $€ 27,500$.

69 Permanent tax measures affecting the variable salary components (or bonuses) in the financial sector have been proposed in Luxembourg and Switzerland. In Luxembourg, a bill submitted to Parliament in May 2010 introduces restrictions on the deductibility of excessive bonuses and golden handshakes in the banking sector and for multinationals. In Switzerland, according to a proposal of the Federal Council presented in April 2010, bonuses that depend on company profits paid by banks and insurance companies should no longer be treated as business expenses for tax purposes, but as profit distribution and therefore be taxable as corporate profits.

70 In January 2010 the Obama administration introduced a plan for a 0.15 per cent Financial Crisis Responsibility Fee to be applied to businesses that had received TARP money. The fee would be levied on the debts of financial firms with more than $\$ 50$ billion in consolidated assets. See The White House, Remarks by the President on the Financial Crisis Responsibility Fee, 14 January 2010. 
US, the dramatic growth of stock-based remuneration plans may have been fostered by specific tax provisions, or by a combination of tax and other rules. Overall, economic analysis suggests that the key to eliminating improper incentives to risk-taking and improving the neutrality of the tax system towards different forms of remuneration is to be found in country-specific measures rather than in general policy guidelines for the abolition of concessionary schemes.

Moreover, to better align the incentives of managers with those of the firm and generate positive synergies with the ongoing reforms of corporate governance affecting remuneration policies, the tax treatment of stock option plans should aim to ensure tax neutrality only to plans that meet given conditions (minimum vesting periods, prohibition of renegotiation in case of falling stock prices, etc.). Those not meeting the conditions should be taxed more heavily than ordinary salary.

\subsection{Venture capital, private equity, hedge funds: the "carried interest" controversy}

In the second half of the last decade, high investor demand and cheap loan finance led many private equity funds to engage in aggressive highly leveraged corporate restructurings aimed at maximizing the fund's short-term performance but often paying little heed to the firms' long-term prospects and resulting in staff redundancies, wage reductions, etc. The growth of private equity transactions prompted ever greater risk-taking and highly leveraged deals.

Among the tax factors that might have reinforced this trend - including the possibility to shift debt acquired to finance the deals onto target companies, which could deduct debt interest, or the tax haven location of many private equity and hedge funds, permitting zero taxation at fund level and opportunities for evasion for high-wealth investors - the tax treatment of private equity and hedge fund managers' remuneration attracted much attention.

Managers of venture capital and private equity funds receive most of their compensation in the form of "carried interest", i.e. as a share of the funds' realized profits on its investments above a certain threshold. ${ }^{71}$ In several countries, notably those with the most private equity funds (the UK and the US), the carried interest is taxed at preferential capital gains rates rather than ordinary income tax rates. In several cases the favourable tax treatment also applies to managers of hedge funds, whose remuneration structure often follows that of private equity funds. It has been argued that this tax treatment is inappropriate, since it taxes as dividends or capital gains what is effectively labour income. Since remuneration based on carried interest is likely to encourage risk-taking, the favourable tax treatment of carried interest may have reinforced this effect. From a purely economic viewpoint, it is hard to justify taxing risky compensation at lower rates than other compensation. And to the extent that carried interest can be qualified as service or labour income, taxing it more favourably than other forms of compensation for risk-taking activities can hardly be justified on grounds of efficiency and equity. ${ }^{72}$ On the contrary, taxing carried interest on a par with other,

71 A venture capital or private equity fund manager is usually the general partner in a fund partnership, and is typically rewarded with a 2 per cent management fee and 20 per cent share of the realized profits on investments above a certain threshold. This 20 per cent profit share is known as "carried interest", because the financial capital underpinning it is provided or "carried" by investors, who are limited partners, even though the management expertise, or "sweat equity", which also contributes to the profit, is provided by the fund manager.

72 Critics of the capital gains tax treatment of carried interest observe that there are two key reasons to conclude that carried interest ought to be categorized as compensation for services, and not as capital gains. First, private equity fund managers are not putting their own financial capital at risk. A basic standard for establishing whether income constitutes capital gains would seem to be whether the individual receiving the income had capital at stake. General partners of private equity partnerships get the 20 percent in return for management services, not because they put 20 percent of the money in the investment pot. Managers do sometimes make a small contribution of capital to the fund. When this occurs, a small share of the carried interest could be considered a financial investment. But the amount managers contribute is typically between 1 and 5 percent - not 20 percent — and the carried interest income attributable to it can be separated out and treated differently under the tax code. Second, private equity managers are performing a service, for which the carried interest is clearly compensating them. Unlike limited 
economically equivalent forms of income would yield tax equity and efficiency at the same time, and probably limit aggressive risk-taking by private equity managers.

In response to criticism of the excessive remuneration of private equity fund managers, since 2007 several European countries have tightened the tax rules on carried interest. In 2008 the UK repealed the tax advantage for carried interest, which had been subject to a capital gains tax of 10 per cent, introducing a general rate of 18 per cent for all capital gains, including carried interest. Germany reduced the exempt percentage of carried interest from 50 to 40 per cent and introduced more specifically targeted tax rules for venture capital and private equity. In 2009 the Netherlands made many forms of deferred compensation, including carried interest, subject to progressive income tax, in the context of the new rules on the "excessive remuneration schemes" recalled above.

The debate on limiting the tax benefits for carried interest has also been lively in the United States, particularly following the biggest buyout boom in history in 2007, when firms including Blackstone Group LP and Och-Ziff Capital Management Group raised their profiles through public stock listings. Bills were presented in Congress, but no legislative change ensued. In February 2010 President Obama presented the 2011 budget proposal, containing provisions to treat carried interest as ordinary income. This would boost the tax rate, starting in 2011, to 39.6 per cent for most executives, from the current 15 per cent capital gain tax rate.

\section{The development of structured finance: the role of taxation}

\subsection{Structured finance}

In this section we consider the possible role of taxation in facilitating or encouraging the development of structured finance, the sector of finance specialized in risk transfer. It is generally acknowledged that structured finance played a key role in the financial crisis. The spread of assetbacked securities (ABSs) and credit derivatives, designed to transfer and reduce (or increase) exposure to credit risk, paved the way for the diffusion of toxic assets and the rise of a "shadow banking system" (Onado, 2009).

Structured finance's chief objective is the transfer of risk between financial intermediaries and investors; it is based on securitization technique. There are several definitions of securitization. ${ }^{73}$ Broadly speaking, the securitization process transforms a financial relationship into a market transaction. More specifically, an "asset securitization" is composed of two stages: a) transfer of a pool of assets from the original owner (the originator) to a finite-lived, stand-alone special vehicle (special purpose entity - SPE, or special purpose vehicle - SPV); b) issuance of securities by the $\mathrm{SPV}$, in order to finance the purchase of the assets. ${ }^{74}$

partners, they are responsible for making investment decisions and managing investments. The main argument that has been offered in defence of treating carried interest as capital gains is that it entails a lot of risk. However, the character of carried interest income should not depend on whether the compensation is performance-based. A wide range of performance-based compensation, including arrangements in which service providers accept the entirety of the risk of the success or failure of the enterprise, is effectively labour income and taxed as ordinary income for services. See the Statement of Peter R. Orzag before the Committee on Finance of the United States Senate, The Taxation of Carried Interest, 11 July 2007.

73 For a more detailed discussion of securitization and structured finance, see Scott (2004), BIS (2005), Duffie (2008), Fabozzi and Khotari (2007), and Lucas, Goodman, and Fabozzi (2007).

74 This analysis does not consider the legal issues of securitization, i.e. the "true sale" of the assets and the "bankruptcy remoteness" of the SPV; on these issues, see Fabozzi and Khotari (2007) and Johnsen and Eagan (2003). 


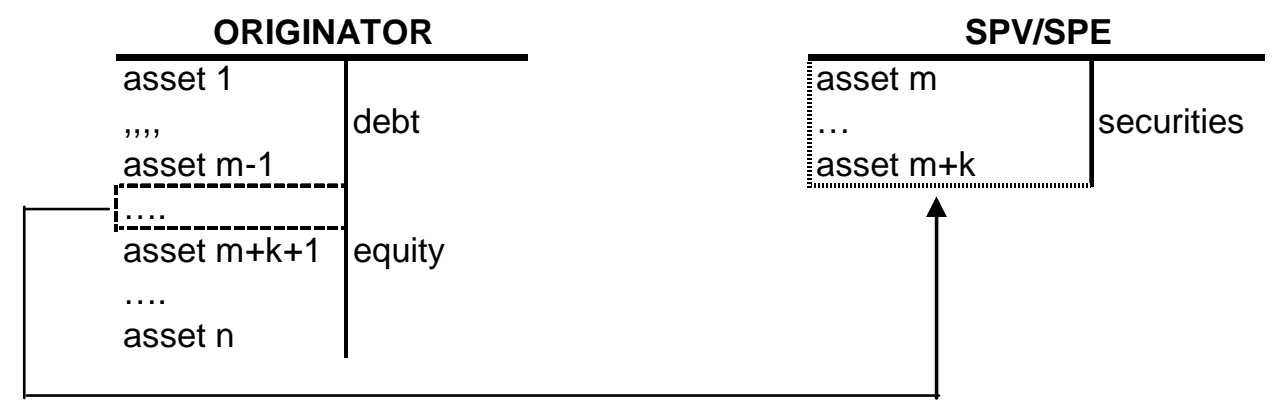

The repayment of principal and interest of securities issued by the SPV is ensured by the cash flow deriving from the assets sold by the originator. As regards SPV structures, there are "pass through SPVs" and "pay through SPVs". In the former, the SPV issues securities representing an undivided right to a pro-rata share of the cash flows deriving from the originator assets; in the latter, the SPV reconfigures the cash flows deriving from the originator's assets, in order to issue several classes of securities, each one with different seniority and distinct risk-return profiles, ranging from AAA bonds to equity. This permits investors seeking higher yields to have a wider choice on the financial market. The securities issued by the SPV are generally called ABSs (asset-backed securities). ${ }^{75}$

The SPV can be created not by an originator but by a financial intermediary, who buys assets (loans or bonds) on the market and puts them in an SPV; in this case, the securitization process creates securities called collateralized debt obligations $\left(\mathrm{CDOs}^{76}\right)$, issued in several tranches with different levels of risk; the SPV is often referred to as a CDO. A CDO usually has fewer financial instruments as collateral than an ABS. ${ }^{77}$

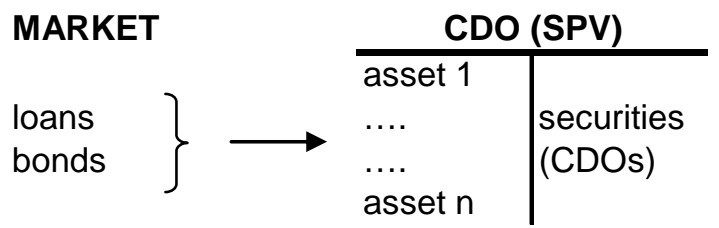

A synthetic CDO is a CDO whose underlying portfolio consists mainly not of bonds but of credit default swaps (CDSs). CDSs are contracts intended to protect a party (the protection buyer) against credit risk. ${ }^{78}$

75 There are several kinds of ABSs, depending on the type of asset sold by the originator. The most important are mortgage-backed securities (MBSs), which can be divided between commercial MBSs (CMBSs), secured by commercial and multifamily properties, and residential MBSs (RMBSs). ABSs are backed also by home equity loans, car loans, consumer loans and credit card receivables. Most mortgage-backed securities are issued by US government agencies, such as the Government National Mortgage Association (Ginnie Mae), the Federal National Mortgage Association (Fannie Mae) and the Federal Home Loan Mortgage Corporation (Freddie Mae), which began mortgage securitization in late 1970s. The first non-Agency mortgage securitization was set up by Bank America in 1977 (Johnsen and Eagan, 2003).

76 CDOs collateralized by bonds are called CBOs; if loans are the collateral, we have CLOs. CDOs can be backed by ABSs and MBSs too, usually by mezzanine tranches: in this case we have structured finance CDOs (SF CDOs). CDOs collateralized by other CDOs are called CDOs squared.

77 For a fuller description of the differences between CDOs and ABSs, see Mason et al. (2007).

78 More specifically, a CDS is a contract where one party buys credit protection on a reference entity (bonds, loans, etc.) from the other party. The credit protection buyer pays a fee during the term of the contract unless and until a credit event (bankruptcy, default, etc.) regarding the reference entity occurs; in this case the credit protection seller must refund the buyer's loss. 


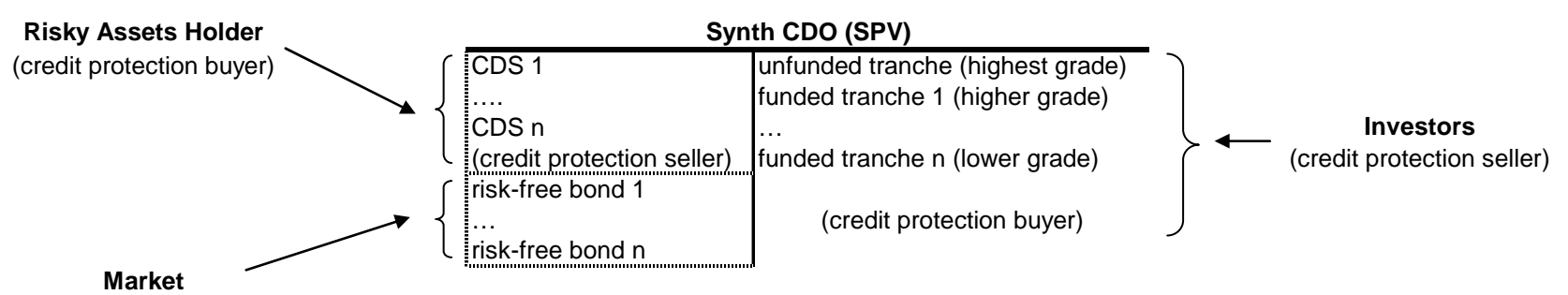

In this case, the SPV sells protection against credit risk via CDSs; at the same time, by selling tranches of synthetic CDOs to investors, it buys protection from them. In this way, synthetic CDOs create credit exposures for investors (Nomura, 2004, Remolona and Shim, 2008). In other words, with synthetic CDOs "credit risk exposure is transferred via CDS rather than the transfer of ownership of corporate debt obligations" (Lucas, Goodman, and Fabozzi, 2007).

Compared with CDOs or ABSs, a synthetic CDO works differently. In fact, tranches may be funded or unfunded. The investor pays an amount to subscribe a CDO's funded tranche, in order to receive interests, in addition to the premium linked to the CDSs' risks. If the investor subscribes an unfunded tranche, he subscribes the CDSs contract alone, without investing any capital, and receives a periodic premium; in other words, subscribing an unfunded tranche is the equivalent of subscribing a CDS on the whole underlying portfolio of the synthetic CDO. The unfunded tranche has the highest grade (i.e., it is the less risky) and may have to make a payment to the synthetic CDO only in the event that the portfolio's losses are not covered by the funded tranches' principal.

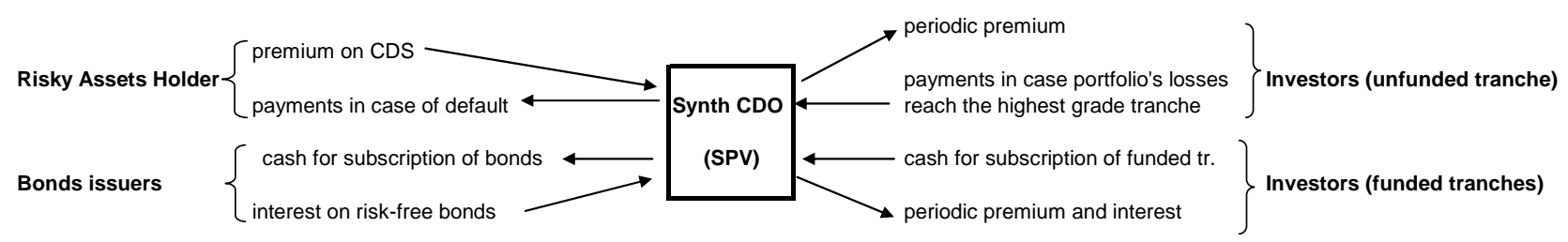

Obviously, ABSs, CDOs and synthetic CDOs can be linked to get more sophisticated structures. Imagine, for example, a bank that securitizes mortgages in an SPV that issues MBSs; the MBSs become collateral of a CDO; the risk of CDOs is insured by a synthetic CDO, and so on.

Summing up, there is structured finance when three main features are present: a) asset pooling; b) issue of several classes of liabilities; c) an SPV, which breaks the link between the credit risk of the asset pool and the credit risk of the original asset holder (BIS, 2005).

There are many reasons for using securitizations: e.g., reducing funding costs; diversifying funding sources; managing corporate risks; achieving off-balance-sheet financing; lowering the cost of capital; removing assets from balance sheets; converting illiquid assets into marketable securities; for CDOs, also increasing asset management activity and profitability (Fabozzi and Khotari, 2007; Nomura, 2004). These incentives can explain the rapid growth of ABSs and CDOs and the demand of banks for new "raw materials" (loans, also of subprime quality). According to some authors (Shin, 2009; Onado, 2009), because of the advantages of securitizations, the growth of subprime mortgages is due more to a loan supply excess from banks than to a loan demand excess from subprime borrowers.

In the next section we point out the role of taxation in this escalation, referring in particular to the US tax rules.

\subsection{The role of taxation in the development of securitization}

It has been pointed out that "tax planning in the securitization area is generally defensive rather than offensive. Transactions are undertaken for non-tax reasons ..." (Peaslee and Nirenberg, 2001). In other words, "the potential [tax] abuses in the securitization area appear ... to be a pimple 
on the back of an elephant." (ibidem). Nevertheless, even if there is no direct tax advantage for the originator or the intermediary, a securitization may have important indirect tax advantages.

\subsubsection{The tax advantages of pooling}

One of the main advantages of securitization is the possibility of pooling assets with different maturity and income characteristics, in order to issue securities without any link to the collateralized asset. From a tax point of view, the assets pooled bear interest and capital gains/losses that could not be taxed at the same rate (e.g., in the US individuals are taxed at the ordinary personal income tax rates on interest income and at special - lower - rate on capital gains/losses) and at the same time. So, reconfiguring assets also means mixing interest and losses; in this way, the value of a capital loss is greater than before securitization, because losses can be offset not only with capital gains (saving an amount of capital gains tax), but also with interest (saving a higher amount of taxes). In other words, securitization moves the taxable event from individual positions (interest and gains/losses on single assets, received from each asset) to the overall result of the pool of assets (the sum of interest, gains and losses from all assets), reducing the expected tax liability (Eddins, 2009). Moreover, the timing structure of flows received from securities issued by the SPV produces a tax advantage in terms of tax deferral: offsetting between interest and losses makes it possible to defer the taxation of the revenues until the SPV distributes incomes on the securities it has issued (or the securities issued by the SPV are sold and capital gains realized).

To reach these goals, it is essential to avoid taxation of the SPV. In fact, only in this case is it possible to: 1) eliminate the tax otherwise due if assets remained in the original asset holder's balance sheet; 2) shift the taxable event from the taxation of principal and interest stemming from the original assets to the taxation of flows received on the securities issued by the SPV.

\subsubsection{The US tax treatment of special purpose vehicles}

Taxation of an SPV can be avoided if the SPV is considered a conduit for US tax purposes or a tax-free offshore entity. ${ }^{79}$ Conduit status for tax purposes is achieved through the check-the-box regulation or compliance with the requirements established for some securitization vehicles: REMIC (real estate mortgage investment conduit, for MBSs), FASIT (financial asset securitization investment trust, for ABSs). ${ }^{80}$

Initially, amendments to tax rules were designed to remove hurdles to the growth of the securitization market development. The introduction of the REMIC regime, in 1986, of the FASIT regime, in 1996, and of the check-the-box regulation, in 1997, allowed greater flexibility in designing securitizations and made market development easier (Nomura, 2006) ${ }^{81}$ According to Peaslee and Nirenberg (2001), "the advent of the REMIC rules has led to a blossoming of financial engineering in the mortgage-backed securities area". ${ }^{82}$ Under these rules a SPV is considered a conduit for tax purposes, but, at the same time, in order to preclude tax avoidance, limits are set on allowable securities, substitution of mortgages, cash contributions to the SPV, etc.

As housing prices began to decline in 2006 and it became clear that a substantial portion of subprime residential adjustable-rate mortgages would not survive the interest rate resets, efforts

79 CDOs are usually issued by offshore SPVs, in order to escape taxation on corporate income (Lucas, Goodman, and Fabozzi, 2007).

80 These vehicles are not subject to federal corporate tax, but may be subject to state taxes.

81 REMICs were introduced by the Tax Reform Act of 1986. The FASIT regime, created under the Small Business Job Protection Act of 1996 and effective from 1997, was subsequently repealed and has not been enforceable since 1 January 2005.

82 Due to temporal mismatching between proceeds from assets held by the vehicle and payments on the securities it issues, in some periods taxable income exceeding economic income may have to be recognized. The excess, i.e. the difference between taxable income and economic income, is called phantom income and constitutes ordinary taxable income for holders of equity interests in a REMIC. For more information, see Lupo (2008). 
were begun to renegotiate the terms of these loans in order to avoid a surge of defaults. These efforts were hampered by the fact that the mortgages had been packaged into REMICs or other investment trusts, where the ability to modify mortgages is severely limited by tax rules designed to ensure that the investment trust maintains a substantially fixed pool of mortgages. Modifying mortgages held by a REMIC can make the vehicle subject to severe penalties, including a 100 per cent prohibited-transaction tax or even possible loss of REMIC or investment trust status altogether.

As the financial crisis made it necessary to renegotiate mortgage loans, the Internal Revenue Service (IRS) issued tax guidance ${ }^{83}$ providing a safe-harbour list of permitted modifications in REMICs (Beeman, 2009).

In some circumstances, avoiding the taxation of SPV may have contributed to the growth of securitization. Due to the corporate taxation of bank income, some banks may have an incentive to sell loans and this incentive is an increasing function of the corporate income tax rate (Han et al., 2010).

At least other three tax issues may play an important role in securitization (Johnsen and Eagan, 2003; Peaslee and Nirenberg, 2001). The first is the characterization of the originator's transfer of assets to the SPV, which for tax purposes may be treated as either a sale of assets (the originator recognizes gains or losses on the transfer) or a loan secured (without any transfer of tax ownership). The second issue regards the tax characterization of securities issued by the SPV as debt or equity; if an investor is treated as an equity owner, he could be taxed on the SPV's residual taxable income emerging in any period (so-called phantom income, see note 82). The third issue concerns the tax treatment of credit default swaps (CDSs), which we analyze below.

\subsubsection{The taxation of credit default swaps}

The taxation of CDSs has enhanced the development of structured finance through two mechanisms:

- a tax arbitrage, created by asymmetries and inconsistencies in the tax treatment of the parties to the CDS contract (the credit protection seller and the credit protection buyer; hereinafter "seller" and "buyer"); these problems arise in turn from the uncertainties in the qualification of CDSs for tax purposes;

- a de facto exemption from withholding tax (or insurance excise tax) on CDS premium received by non residents, complementing the tax arbitrage mechanism.

Qualification. The tax treatment of CDSs in the US is still a matter of debate. ${ }^{84}$ The IRS issued a notice requesting information from market participants and experts in 2004, but has yet to issue specific tax guidance on the matter; meanwhile, recent developments in the market of CDSs (standardization, significant upfront payments, etc.) have increased the complexity of tax issues. ${ }^{85}$ Taxpayers can only rely on the opinion of tax experts, who do not even agree on the approach to analyzing the problem and propose two different methods:

- the analogy approach, with CDSs held to be analogous to other derivatives and the same tax treatment applied;

- the analytical approach, with the tax treatment of CDSs derived by analyzing single elements of the transactions, e.g. the nature of the reference obligation, the nature of parties, etc.

83 IRS rev. proc. 2007-72, 2008-28, 2008-47. Initial attempts to relax these rules had been made in 2004 and 2005.

84 "The current state of taxation of financial instruments is a mess ... Credit default swaps present a case study of much that is wrong with the extant method of rule promulgation. ... [T] he tax treatment of financial innovation continues to be regulated in ... a haphazard 'cubbyhole' approach" (Brunson, 2008, passim).

85 See Munro (2010), passim. 
The literature has paid little attention to the analytical approach, perhaps because tax rules operate first "by characterizing a financial contract as a type of financial instruments ... and then by taking context into account" ${ }^{86}$ By contrast, the analogy approach has been extensively pursued and ultimately turned into four different theories: a CDS has been compared to a guarantee, an insurance contract, a notional principal contract (NPC) or a (put) option. This list has been considered exhaustive in absence of "similar breadth and depth of tax law for other potential analogies" 87 (i.e. letter of credit).

Analyses have substantially rejected the first two hypotheses, underlining significant and detailed differences between a CDS and a guarantee ${ }^{88}$ or an insurance contract ${ }^{89}$; in general, CDSs like all financial derivatives - have latu sensu a guarantee/insurance function, but this not necessarily imply that they are legally equated with those operations. Most opinions (and recommendations) qualify CDSs as NPCs or options, but there is still debate on which of these definitions is more appropriate. An NPC ${ }^{90}$ like a CDS, is a financial instrument providing payments at specified intervals, by reference to a specified index on a notional amount and in exchange for specified consideration or a promise to pay a similar amount; but the payments to the credit protection seller should be taxed/deducted over the life of NPC, whereas the life of a CDS cannot be known in advance. An option, like a CDS, is a continuing offer plus an agreement to leave the offer open, but the condition for exercise is the occurrence of a default and not a mere decision of the credit protection buyer. ${ }^{91}$

Tax treatment of parties involved. Following the general rules on the taxation of securities, the tax treatment of operation with CDSs depends on two major variables: characterization either as capital gains or losses, taxed or deductible at 15 per cent, or as ordinary income, taxable or deductible at 35 per cent for corporations and at the ordinary income tax rates for individuals; timing, with the different options of taxation on a cash basis, for mere investors, an accrual (mark-to-market) basis, for dealers and traders in securities.

Usually, the credit protection buyer is an investor and his credits are capital assets, while the seller is a dealer or a trader. Accordingly, a loss incurred on a credit by a non-corporate credit protection buyer will be treated as a capital loss deductible at 15 per cent and netting will be allowed primarily within " 15 per cent group" gains $;{ }^{92}$ the refund the credit protection buyer receives from seller must be treated in the same way of the loss.

As for timing, the credit protection buyer will always account for the loss only when it is realized, on a cash basis, whereas the seller is a mark-to-market operator and is taxed on an accrual basis, including the gains or losses in its income subject to corporate income tax.

- If we qualify CDSs as guarantees or insurances, the buyer will treat the refund of loss received from the seller as a capital income ( 15 per cent); the seller will treat all the payments made or received as ordinary income or expense ( 35 per cent). As for timing rules, while the buyer has

${ }^{86}$ NYSBA (2005), p. 566.

87 NYSBA (2005), p. 567.

88 In CDSs the buyer is not required to hold the reference obligation, has no right of subrogation in a case of default and his payment obligation is always directed to the seller, not to a third party. In addition CDSs are traded, generic and standard, while guarantees are usually non-traded and specific.

89 In a CDS, a) the credit event is not triggered by a "fortuitous event"; b) the loss lacks the classical elements of loss in insurance contracts (timing, quantification in advance, no insurable interest if the buyer does not hold the reference obligation, absence of pooling and dilution of risk); c) sector regulations permit banks but not insurance companies to engage in CDSs.

90 The definition of NPC encompasses interest rate swaps, basis swaps, currency swaps, interest rate caps, interest rate floors, equity swaps, and equity index swaps; options are excluded.

91 For a discussion on replacing "the customary definition of options in terms of the 'rights' of the parties with a definition that better reflects the true economics of options", see Brandes (2008), in particular pp. $80 \mathrm{ff}$.

92 Further netting is allowed within " 25 per cent group" and, finally, " 28 per cent group" capital gains. 
only the option for realization, the loss of the seller may be treated through a bad-debt deduction (guarantee) or an estimated loss (insurance).

- If CDSs are equated with NPCs, the tax characterization of payments made and received by the buyer and the seller are in principle the same as in guarantees or insurance contracts. Timing: both the buyer and the seller must account for the payment of premiums on an accrual basis, but the seller can also mark CDSs to market.

- CDS-options are deemed to be a capital asset under Sec. 1234 of the US tax code, so all payments made and received by the buyer are not ordinary income or expense, but capital losses/gains, deductible or taxable at the expiration of the option. The seller has no capital gain or loss but only ordinary income or expense and marks CDSs to market.

Summing up, the tax treatment of operations involving CDSs is characterized by asymmetries and inconsistencies, because of the differences between buyers and sellers in respect of the tax characterization of items and the timing of taxation. The different views on the nature of CDSs do not eliminate these problems: for example, if we qualify a CDS as a NPC for hedging, we can apply the same tax treatment to buyer and seller, but an asymmetry remains for the buyer between the loss and the refund. Including CDSs in the general tax treatment of securities, the qualification by analogy always creates room for tax arbitrage.

The tax arbitrage mechanism. Eddins ${ }^{93}$ has developed a theory (tax arbitrage feedback theory) about how these tax arbitrage opportunities have been exploited. Simplifying the situation described above, he identifies three different players: "traditional buy and hold investor", with interest taxed as ordinary income and losses deductible as capital items at a different rate; "mark-to-market business trader", with interest and losses accounted for as ordinary income, at the same rate; and "non-taxable investor" (such as pension funds).

The asymmetric tax treatment of interest versus losses creates a tax penalty for traditional investors. Since this tax asymmetry does not exist for mark-to-market operators (and non-taxable investors), the premium paid for CDSs includes this tax penalty and the mark-to-market operator is able to extract and retain this tax penalty, transforming a tax loss deductible at 15 per cent into a loss deductible at 35 per cent. The "Credit Default Swap Tax Arbitrage Equation" is the following:

$$
\text { TaxPenalty }=\beta \times(1-R) \times \frac{\left(T_{\text {Interest }}-T_{\text {Loses }}\right)}{1-T_{\text {Interest }}}
$$

where $\beta$ is the annualized bankruptcy risk, $\mathrm{R}$ the expected recovery rate and $\mathrm{T}_{\text {Interest }}$ and $\mathrm{T}_{\text {Losses }}$ are, respectively, the tax rates on interest and losses of a traditional investor. The arbitrage profit depends primarily on the difference between the tax rates, but it also increases as $\beta$ and $\mathrm{R}$ increase: the higher the risk, the greater the profit. Therefore, the "tax penalty" represents the arbitrage profit of the mark-to-market operator. "And because this arbitrage is tax-based, instead of price-based, it cannot be eliminated by price moves". 94

The profit opportunity has a feedback: to exploit it operators need CDSs, and CDSs need lowgrade credit. The consequence is a multiple boost affecting different markets: loans increase to supply the raw materials of the chain, CDSs increase to extract risk from loans in exchange for protection, and CDOs increase to buy from investors the protection sold through CDSs. As Eddins observes, "this particular tax arbitrage does not exist for high-grade credit because the odds of default are so low that there is hardly any tax benefit to arbitrage. Therefore, the creation of lowgrade credit was a requirement to fuel the arbitrage. The extreme profitability of these businesses to Wall Street provided powerful feedback to induce the creation of lots of low-grade debt. Unrecognized was the fact that increasing the quantity of low-grade credit within the financial

\footnotetext{
93 See Eddins (2009).
}

94 Ibidem, p. 19. 
system also increased the systematic risk of default. This set off a chain reaction that spread far and wide". 95

There only remains a final point to analyze, one not mentioned by Eddins: as the arbitrage profit is extracted by the mark-to-market operator via the CDS premium (which is equal to the tax penalty), can the taxation of the CDS premium compensate for (or at least reduce) the arbitrage profit?

Taxation of CDS premiums received by non-residents. As noted by the Internal Revenue Service, ${ }^{96}$ taxpayers are also concerned about the treatment of payments from a credit protection buyer in the US to a non-resident credit protection seller. The question is whether these payments are subject to taxation in the US, either through a withholding tax or through an excise tax on insurance premiums. $^{97}$

Let us recall that non-residents are taxed on US-source income only if it is effectively related to a US trade or business (that is, a regular, continuous and considerable business); unrelated income is taxed if particular conditions obtain. ${ }^{98}$

If we consider the four possible characterizations of CDSs, we find that these instruments are subject to virtually no form of taxation in the US when the recipient is a non-resident.

- We have already shown why CDSs appear quite different from guarantees. But even if they were comparable, this would not lead to the taxation of payments to a non-resident: a guarantee is not necessarily subject to withholding tax, because it is not necessarily related to a US trade or business (and this is even more likely for a CDS); the Internal Revenue Service does not cite guarantees among US source items, and it is an open question whether the proceeds of a guarantee can be equated with payment of interest.

- Even if the definition of insurance does not appear to apply to CDSs, let us consider CDSs as insurance contracts: if the seller is not an insurance firm, then it is not engaged in an insurance activity; consequently, the US source premium is not US source income and is not subject to withholding tax. In respect of the excise tax of 4 per cent on the premiums paid by a US insured-party to a non-US insurer and levied when the risk is located wholly or partly within US, CDS contracts may provide that the buyer be indemnified against the risk of paying excise tax via a premium increase. In this case, again, non-residents are not taxed.

- We have shown that CDSs appear to fit the definition of NPCs; as income from NPCs is not mentioned in the sourcing rules of the US tax code and the Internal Revenue Service defines the source of such income on the basis of the taxpayer's residence, the income is not taxable in the USA if the credit protection seller is a foreigner. Again, the CDS payments received by the seller are tax exempt in the US.

- CDSs could be considered as options. Again, income from option premiums is not mentioned in the sourcing rule; the IRS has not ruled on it, so no withholding tax is levied. Consequently, such income is US source income non-taxable in the US.

To conclude: it is an open question whether a CDS-guarantee should be subject to withholding tax. It is possible that a CDS-insurance holder could also be exempted de facto from the excise tax. A CDS-NPC holder can escape the withholding tax. Finally, it is almost certain that no tax is levied on premiums received from a CDS-option. The tax arbitrage described above is accompanied by a de facto exemption of CDS premiums received by non residents.

95 Ibidem.

96 IRS (2004).

97 For a deeper discussion, see Peter (2006).

98 The income is US source and falls under sec. 861 or was allocated by regulations to sources within the US or is allocated by comparison and analogy; income must be fixed, determinable, annual or periodic. 


\section{References}

Aldeweireldt, J. (2002), "Tax Treatment of Employee Stock Options: An International Comparison", Tax Notes International, Vol. 27, No. 8 - August 19, 2002, pp. 951-953.

Anson, M. J., F.J. Fabozzi, M. Choudhry and R. Chen (2004), Credit derivatives. Instruments, applications, pricing, Wiley, 2004.

Bajaj, V., D. Leonhardt (2008), “Tax Break May Have Helped Cause Housing Bubble”, New York Times, December 18, 2008.

Balsam, S., R. Halperin, H. Mozes (1997), "Tax Costs and Nontax Benefits: The Case of Incentive Stock Options", Journal of the American Taxation Association, Vol. 19, No. 2 - Fall 1997, pp. 1937.

Beeman, R.E. (2009), “A Compendium of Financial Crisis Tax Guidance”, Bank Accounting \& Finance, Vol. 22, No. 1 - February/March 2009, pp. 3-13

Bernanke, B., M. Gertler (1995), "Inside the Black Box: The Credit Channel of Monetary Policy Transmission", Journal of Economic Perspectives, Vol. 9, No. 4 - Autumn, 1995, pp. 27-48.

Biehl, A.M., W.H. Hoyt (2008), “The Taxpayer Relief Act of 1997 and homeownership: is smaller now better?”, IFIR Working Paper No. 2009-04, 2009.

Bier, T., I. Maric, W. Weizer (2000), "A preliminary assessment of the new home seller capital gains law”, Housing Policy Debate, Vol. 11, No. 3 - 2000, pp. 645-673.

BIS - Bank for International Settlement (2005), Committee on the Global Financial System, The role of ratings in structured finance: issues and implications, January, 2005.

Borselli, F., A. Buoncompagni and S. Manestra (2010), "Residential real estate taxation in Europe: actual burden on ownership and investment", European Taxation, Vol. 50, No. 10 - October 2010, pp. 457-464

Brandes, A.J. (2008), "Toward a New Framework and a Better Understanding of Credit Default Swaps", Derivatives and Financial Instruments, Vol. 10, No. 3 - May/June 2008, pp. 75-91.

Brunson, S.D. (2008), "Elective taxation of risk-based financial instruments: a proposal", Houston Business and Tax Journal, Vol. 8, Part 1 -2008, pp. 1-36.

Bucks, B.K., A.B. Kennickell, T.L. Mach, K.B. Moore (2009), “Changes in U.S. Family Finances from 2004 to 2007: Evidence from the Survey of Consumer Finances”, Federal Reserve Bulletin, Vol. 95, February 12, 2009.

Buiter, W. H. (2008), “Housing wealth isn't wealth”, NBER Working Paper, No. 14202, July, 2008

Bulow, J., J.B. Shoven (2005), “Accounting for Stock Options”, Journal of Economic Perspectives, Vol. 19, No. 4 - Autumn 2005, pp. 115-134.

Burman, L. (2008), "Did the capital gains tax break on home sales help inflate the housing bubble?". Available at http://taxvox.taxpolicycenter.org/blog/_archives/2008/12/22/4031629.html.

Carter, M.E. , L.J. Lynch, I. Tuna (2007), "The Role of Accounting in the Design of CEO Equity Compensation", The Accounting Review, Vol. 79, No. 2 - March 2007, pp. 251-275.

Case, K.E. , R.J. Shiller (1988), "The behaviour of home buyers in boom and post-boom markets", New England Economic Review, November/December 1988, pp. 29-46.

Case, K.E., R.J. Shiller (2004), “Is there a bubble in the housing market?", Cowles Foundation Paper No. 1089, 2004.

Cohen, F. , P.M. Panteghini, L. Valdameri (2006), "Employee Stock Options: Italy and the World", Tax Notes International, Vol. 44, No. 12 - December 18, 2006, pp. 965-970. 
Cunningham, C.R., G.V. Engelhardt (2008), "Housing capital-gains taxation and homeowner mobility: evidence from the Taxpayer Relief Act of 1997', Journal of Urban Economics, Vol. 63, No. 3 - May 2008, pp. 803-815.

Duffie, D. (2008), "Innovations in Credit Risk Transfer: Implications for Financial Stability”, BIS Working Paper No. 255, July 2008.

ECB (2003), Structural factors in the EU housing markets, March, 2003.

Eddins, S.T. (2009), "Tax Arbitrage Feedback Theory”, March 9, 2009. Available at http://ssrn.com/abstract=1356159.

European Commission (2009a), Recommendation on remuneration policies in the financial services sector, C(2009) 3159, Brussels, April 30, 2009.

European Commission (2009b), Recommendation complementing Recommendations 004/913/EC and 2005/162/EC as regards the regime for the remuneration of directors of listed companies, C(2009) 3177, Brussels, April 30, 2009.

Fabozzi, F.J., V. Khotari (2007), Securitization: The Tool of Financial Transformation, Yale ICF Working Paper No. 07-07, 2007. Available at http://ssrn.com/abstract=997079.

Fehr, H., L. Knoll, L. Mikus (2004), “Taxation of Stock Options: An International Comparison”, Tax Notes International, Vol. 33, No. 5 - February 2, 2004, pp. 463-472.

Financial Stability Forum (2009), Principles for Sound Compensation Practices, April 2, 2009.

Gjerstad, S., V.L. Smith (2009), "From bubble to depression?”, Wall Street Journal Online, April 6, 2009.

Glaeser, E.L. (2009), "Killing (or Maiming) a Sacred Cow: Home Mortgage Deductions", New York Times, February 24, 2009.

Glaeser, E.L., J. Gyourko (2008), Rethinking Federal Housing Policy, AEI Press, 2008.

Glaeser, E.L., J. Gyourko, R.E. Saks (2005), "Why have housing prices gone up?", Harvard Institute of Economic Research, Discussion Paper No. 2061, February 2005.

Glaeser, E.L., J.M. Shapiro (2002), "The benefits of the home mortgage interest deduction”, NBER Working Paper No. 9284, 2002.

Hall, B., J. Liebman (2000), The Taxation of Executive Compensation, in J.M. Poterba (ed.), Tax Policy and the Economy, Vol. 14, MIT Press, 2000, pp. 1-44.

Hall, B., K. Murphy (2003), "The Trouble with Stock Options", Journal of Economic Perspectives, Vol. 17, No. 3 - Summer 2003, pp. 49-70.

Han, J., K. Park, G. Pennacchi, “Corporate Taxes and Securitization”, mimeo.

Hilbers, A., A.W. Hoffmaister, A. Banerji, A. Shi (2008), House price developments in Europe: a comparison, IMF Working Paper No. 08/211, 2008.

Himmelberg, C., C. Mayer C., T. Sinai (2005), “Assessing high house prices: bubbles fundamentals and misperceptions", Journal of Economic Perspectives, Vol. 19, No. 4 - Autumn 2005, pp. 67-92.

Hite, G.L., M.S. Long (1982), “Taxes and executive stock options", Journal of Accounting and Economics, Vol. 4, No. 1 - July 1982, pp. 97-106.

IBFD - International Bureau of Fiscal Documentation (2009), European Tax Handbook 2009, IBFD, 2009.

IBDF - International Bureau for Fiscal Documentation (2010), European Tax Handbook 2010: Ireland, IBFD, 2010. 
IMF (2008), The changing housing cycle and the implications for monetary policy, World economic outlook. Housing and the business cycle, April, 2008.

IMF (2009), Debt Bias and Other Distortions: Crisis-Related Issues in Tax Policy, prepared by the IMF Fiscal Affairs Department, June 12, 2009.

IRS (2004), Request for Information About Credit Default Swaps, Notice 2004-52, 2004.

Jaquette, S., M. Knittel, K. Russo (2003), "Recent Trends in Stock Options." Office of Tax Analysis, Department of Treasury, Working Paper 89. Washington, D.C.

Johnsen, K., M. Eagan (2003), "Tax Treatment of Securitizations of Receivables", Derivatives and Financial Instruments, Vol. 5, No. 6 - November/December 2003, pp. 232-240.

Kats, A. (2009), Our lot: how real estate come to own us, Bloomsbury USA, 2009.

Kearl, J. (1979), “Inflation, mortgages, and housing”, Journal of Political Economy, Vol. 87, No. 5, Part. 1 - October 1979, pp. 1115-1138.

Kiyotaki, N., J. Moore (1997), “Credit Cycles”, Journal of Political Economy, Vol. 105, No. 2 April 1997, pp. 211-248.

Leamer, E.E. (2007), "Housing IS the business cycle”, NBER Working Paper No. 13428, 2007.

Levin, C. (2009), Senate Floor Statement on Introduction of the Ending Excessive Corporate Deductions for Stock Options Act. Available at http://levin.senate.gov/newsroom/release.cfm?id=316068

Lucas, D.J., L.S. Goodman, F.J. Fabozzi (2007), “Collateralized Debt Obligations and Credit Risk Transfer”, Yale ICF Working Paper No. 07-06, 2007. Available at http://ssrn.com/abstract=997276.

Lupo, T.B. (2008), Phantom Income, addendum to Peaslee and Nirenberg (2001). Available at www.securitizationtax.com.

Madeo, S.A., T.C. Omer (1994), "The Effect of Taxes on Switching Stock Option Plans: Evidence from the Tax Reform Act of 1969", Journal of the American Taxation Association, Vol. 16, No. 2 Fall 1994, pp. 24-42.

Mason, J.R. (2009), "Regulating for Financial System Development, Financial Institutions Stability, and Financial Innovation”, April 17, 2009. Available at http://ssrn.com/abstract=1393409.

Mason J.R., J. Rosner (2007), "Where Did the Risk go? How Misapplied Bond Ratings Cause Mortgage Backed Securities and Collateralized Debt Obligation Market Disruptions”, May 3, 2007. Available at http://ssrn.com/abstract $=1027475$.

Miller D.S. (1998), An Overview of the Taxation of Credit Derivatives, in F. J. Fabozzi (ed.), The Use of Derivatives in Tax Planning, Wiley, 1998.

Munro A.B. (2010), "Revisiting Tax Considerations Regarding Credit Defaults Swaps", Derivatives and Financial Instruments, Vol. 12, No. 1 - January/February 2010, pp. 9-15.

Murphy, K. (2002), "Explaining Executive Compensation: Managerial Power versus the Perceived Cost of Stock Options", University of Chicago Law Review, Vol. 69, No. 3 - Summer 2002, pp. 847-869.

Nomura (2004), CDOs in plain English, 2004.

Nomura (2006), MBS Basics, 2006.

NYSBA - New York State Bar Association Tax Section (2005), “Credit Default Swap", Tax Notes International, Vol. 40, No. 6 - November 7, 2005, pp. 545-589.

OECD (2000), United Kingdom , OECD Economic Survey, 2000. 
OECD (2005), The taxation of employee stock options, OECD Tax Policy Study No. 11, 2005.

OECD (2007), Belgium, OECD Economic Survey, 2007.

OECD (2009), Moving beyond the crisis: using tax policy to support financial stability, June, 2009.

Onado, M. (2009), I nodi al pettine, Laterza, 2009.

Owens, J. (2005), "The Intersection of Tax and Good Corporate Governance", Tax Notes International, Vol. 37, No. 9 - February 28, 2005, pp. 767-769.

Peaslee, J.M., D.Z. Nirenberg (2001), Federal Income Taxation of Securitization Transactions, 3rd edition, Frank J. Fabozzi Associates. Updates available at www.securitizationtax.com

Peter, A.F. (2006), "United States. Characterization of Credit Default Swaps for Tax Purposes", Derivatives and Financial Instruments, Vol. 8, No. 1, - January/February 2006, 2006, pp. 1-12.

Poterba, J.M. (1984), "Tax subsidies to owner-occupied housing: an asset-market approach", Quarterly Journal of Economics, Vol. 99, No. 4 - November 1984, pp. 729-752.

Poterba, J.M. (1991), "House price dynamics: the role of tax policy and demography", Brooking Papers on Economic Activity, Vol. 1991, No. 2, 1991, pp. 143-203.

Poterba, J.M. (1992), “Taxation and housing: old questions, new answers", American Economic Review, Vol. 82, No. 2 - May 1992, pp. 237-242.

Quayes, S. (2010), "The impact of capital gains tax exemption on housing sales", Applied Economic Letters, Vol. 17, pp. 213-216.

Remolona, E.M., I. Shim (2008), "Credit derivatives and structured credit: the nascent markets of Asia and the Pacific", BIS Quarterly Review, June, 2008, pp. 57-65.

Scholes, M.S., M.A. Wolfson, M.M. Erickson, E.L. Maydew, T.J. Shevlin (2008), Taxes and Business Strategy, $4^{\text {th }}$ Edition, Prentice Hall, 2008.

Scott, H.S. (2004), International Finance: Law and Regulation, $1^{\text {st }}$ Edition, Sweet \& Maxell, 2004.

Shan, H. (2008), "The effect of capital gains taxation on home sales: evidence from the Taxpayer Relief Act of 1997", Board of Governors of the Federal Reserve System, Finance and Economics Discussion Series No. 53, 2008.

Shiller, R.J. (2005), Irrational exuberance, $2^{\text {nd }}$ Edition, Princeton University Press, 2005.

Shin, H.S. (2009), "Securitisation and Financial Stability", The Economic Journal, Vol. 119, No. 536 - March, 2009, pp. 309-332.

Smith, T., G.R. Huston (2009), "Do Taxes Matter? Evidence of Individual and Corporate Tax Incentives on the Choice to Hold Shares Acquired from Exercise of Employee Stock Options", July 21, 2009. Available at http //ssrn.com/abstract $=1436967$.

Smith, V.L. (2007), “The Clinton Housing Bubble”, Wall Street Journal Online, December 18, 2007.

Sullivan, M.A. (2005), "The Economics of the American Dream", Tax Notes, 106, January. 24, 2005, pp. 407-409.

Sullivan, M.A. (2008), "Deleveraging the tax code”, Tax Notes, 120, September 29, 2008, pp. 1241.

Surowiecki, J. (2009), “The debt economy”, The New Yorker, November 23, 2009.

Topel, R., S. Rosen (1988), "Housing investment in the United States", Journal of Political Economy, Vol. 96, No. 4 - August 1988, pp. 718-740. 
US Department of Housing and Urban Development (2005), At HUD, homeownership is on the front burner, Research Works, Vol. 2, No. 6 - June 2005.

Van den Noord, P. (2005), "Tax Incentives and House Price Volatility in the Euro Area: Theory and Evidence", Économie Internationale, Vol. 101, No. 1, pp. 28-45.

Van den Noord, P., C. Heady (2001), "Surveillance of Tax Policies: A Synthesis of Findings in Economic Surveys", OECD Economics Department Working Papers, No. 303, 2001.

Vink, D., A.E. Thibeault (2008), "ABS, MBS and CDO Pricing Comparisons: An Empirical Analysis", The Journal of Structured Finance, Vol. 14, No. 2 - August 2008, pp. 27-45. 